\title{
Proračunska perspektiva Hrvatske nakon ulaska u Europsku uniju
}

Sopek, Petar

Source / Izvornik: Odabrani prijevodi, 2013, 4, 1 - 33

Journal article, Published version

Rad u časopisu, Objavljena verzija rada (izdavačev PDF)

https://doi.org/10.3326/op.14

Permanent link / Trajna poveznica: https://urn.nsk.hr/urn:nbn:hr:242:672800

Rights / Prava: Attribution-NonCommercial-NoDerivatives 4.0 International/ImenovanjeNekomercijalno-Bez prerada 4.0 međunarodna

Download date / Datum preuzimanja: 2023-04-26

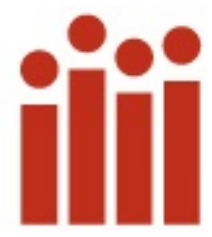

Repository / Repozitorij:

Institute of Public Finance Repository

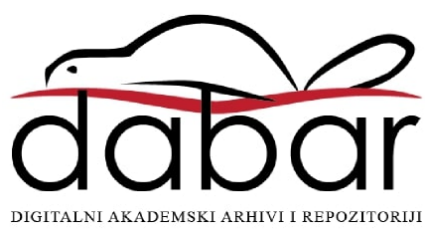


Institut za

javne financije

Smičiklasova 2I | Zagreb

www.ijf.hr | ured@ijf.hr

T: oI/4886-444 | F: OI/48I9-365

\section{ProraČUnSKa PERSPEKTIVA HRVATSKe NAKON ULASKA U EUROPSKU UNIJU}

PETAR SOPEK ${ }^{*}$

\section{ODABRANI PRIJEVODI}

ISSN I847-7445

\section{BR. I4/I3}

citirati: Sopek, P., 20I3. "Budget perspective in Croatia after accession to the European Union". Financial Theory and Practice, 37 (I), 3I-7I. http:/ /fintp.ijf.hr/upload/files/ftp/ 20I3/I/sopek.pdf

Svi Odabrani prijevodi dostupni su na: http://www.ijf.hr/hr/publikacije/ca sopisi/I2/odabrani-prijevodi/III/

\section{SAŽETAK}

Prilikom pristupanja Europskoj uniji (EU) proračun zemlje članice doživljava velike strukturne promjene zbog pojave novih kategorija prihoda i rashoda. Cilj je ovog rada procijeniti moguće učinke članstva Hrvatske u EU na promjene u strukturi i veličini proračunskih prihoda i rashoda po ulasku u Uniju te prikazati mogućnosti za realizaciju sredstava iz europskih fondova u novoj financijskoj perspektivi EU do 2020. Pokazuje se da bi Hrvatska u 2013. trebala ostvariti pozitivnu neto novčanu poziciju u transakcijama s proračunom EU i to u iznosu od oko o,28\% BDP-a, odnosno I36 mil. EUR. Ukupna neto financijska pozicija Hrvatske zbog pristupanja EU u 20I3., koja uključuje još i dodatne troškove i koristi zbog pristupanja, poput raznih usklađivanja te potrebe za sufinanciranjem projekata na državnoj i lokalnoj razini, također je pozitivna i iznosi oko o,I5\% BDP-a ili 72 mil. EUR. Ukupan iznos svih sredstava koji bi Hrvatska mogla primiti u novoj financijskoj perspektivi EU koja obuhvaća razdoblje od 2014-2020. iznosi 6,34 mlrd. EUR, pri čemu se godišnji iznos povećava s o,7 mlrd. EUR u 2OI4. na I,2 mlrd. EUR u 2020. Eksponencijalnom regresijskom analizom procijenjeno je da bi u 2020. Hrvatska trebala biti neto primateljica sredstava iz EU proračuna $u$ ukupnom iznosu od I,43\% BDP-a, odnosno I,O4 mlrd. EUR.

Ključne riječi: Hrvatska, Europska unija, fiskalna politika, članstvo u EU, neto učinci pristupanja, nove zemlje članice

"Autor teksta je zaposlen u Privrednoj banci Zagreb na poziciji glavnog analitičara u Sektoru za upravljanje rizicima. Navodi u tekstu isključivo su osobni stavovi autora te ni u kojem slučaju ne izražavaju stajalište ili mišljenje institucije u kojoj je zaposlen. Autor zahvaljuje dvojici anonimnih recenzenata na korisnim komentarima i sugestijama.

Prijašnja verzija ovog rada predstavljena je na konferenciji Zagrebačke škole ekonomije i managementa New Economic Challenges after EU Accession: What Awaits Us in the Long Run? koja je održana u Zagrebu i8. svibnja 2012.

*** Primljeno: I7. svibnja 2012.

Prihvaćeno: 2. rujna 2012.

\section{Petar SOPEK}

Privredna banka Zagreb, Radnička 48, Io ooo Zagreb

e-mail: Petar.Sopek@pbz.hr 


\section{UvOD}

Europska unija nastavlja pripremu svog daljnjeg širenja. Pristupni pregovori s Hrvatskom završeni su 30. lipnja 20II., a Ugovor o pristupanju (The Accession Treaty) je potpisan 9. prosinca 2011. Na referendumu održanom 22. siječnja 20I2., 66,27\% hrvatskih birača glasovalo je za ulazak Hrvatske u EU. Nakon procesa ratifikacije od strane svih država članica i Hrvatske, pristupanje je predviđeno za I. srpnja 20I3. (Delegacija Europske unije u RH, 20I2).

Članstvo u EU općenito dovodi do brojnih fiskalnih pritisaka. Ti se pritisci očituju u doprinosu zemlje članice zajedničkom proračunu Unije, sufinanciranju projekata, predfinanciranju nekih EU transfera u prvom razdoblju članstva, kao i nastavku implementacije pravne stečevine EU u skupim područjima poput zaštite okoliša, infrastrukture, kontrole granica i javne administracije (Antczak, Dabrowski i Gorzelak, 2004).

Izgradnja administrativne infrastrukture u pretpristupnom razdoblju od iznimnog je značenja, ne samo zbog bolje koordinacije i upravljanja pretpristupnim fondovima, već i zbog adekvatne pripreme za korištenje Strukturnih fondova EU (po dobivanju statusa zemlje članice). Institucije i ljudski potencijali uključeni u procese programiranja, provedbe i evaluacije sredstava Europske unije, ključna su odrednica apsorpcijskog kapaciteta svake zemlje i pokazatelj spremnosti zemlje za učinkovito korištenje raspoloživih sredstava.

Apsorpcija sredstava iz EU fondova generalno ovisi o tri glavne odrednice, a to su makroekonomski, financijski i administrativni, tj. institucionalni apsorpcijski kapaciteti. Makroekonomski apsorpcijski kapacitet važan je zbog otvaranja mogućnosti za dovoljan broj efikasnih investicijskih prilika, administrativni apsorpcijski kapacitet ključna je odrednica uspješnosti implementacije strukturnih politika EU, a financijski apsorpcijski kapacitet definira sposobnost sufinanciranja projekata (Osterloh, 20IO).

Upravo je financijski apsorpcijski kapacitet, koji se definira kao sposobnost sufinanciranja EU programa i projekata, planiranje i garantiranje državnog doprinosa u višegodišnjem proračunu te objedinjavanje doprinosa različitih partnera uključenih u čitav proces, direktno pod utjecajem fiskalne politike. Iz ovoga slijedi da svaka zemlja pristupnica unaprijed mora voditi računa o potencijalnim troškovima procesa pristupanja.

Godišnji prosjek procijenjenih ukupnih troškova prije pristupanja EU za nove zemlje članice (tzv. EUIo) iznosi 3,2\% BDP-a, od čega se iz proračuna opće države prosječno financira iznos od I,6\% BDP-a, ali taj iznos varira od minimalnih o,4\% BDP-a u Poljskoj do maksimalnih 3,6\% BDP-a u Bugarskoj (Antczak, Dabrowski i Gorzelak, 2004; Hallet, 2004). Čak i nakon pristupanja EU, nove zemlje članice imaju visoke fiskalne troškove za razvoj infrastrukture te za reformu javne administracije. Prosječan udio tih rashoda $\mathrm{u}$ BDP-u procijenjen je u rasponu 2-3\% na godišnjoj razini u 8 zemalja koje su postale punopravne članice EU od I. svibnja 2004. (Antczak, Markiewicz i Siwinska, 2006). Stoga proces pristupanja dovodi do negativnog neto fiskalnog učinka na proračun opće države, koji varira ovisno o 
stupnju usklađenosti, a može iznositi čak i do 3\% BDP-a u prvim godinama nakon dobivanja statusa članice (Antczak, 2003).

Cilj je ovog rada procijeniti moguće učinke ulaska Hrvatske u Europsku uniju na promjene u strukturi i veličini proračunskih prihoda i rashoda po ulasku u Uniju te prikazati mogućnosti za realizaciju sredstava iz europskih fondova u novoj financijskoj perspektivi EU do $202 \mathrm{O}^{\mathrm{I}}$. Velik dio analize, uz neke dodatne pretpostavke i korekcije, oslanjat će se na povijesna iskustva novih zemalja članica EU, a kao najvažniji izvor informacija bit će korišten financijski izvještaj Europske komisije o ostvarenim proračunskim prihodima i rashodima u razdoblju od 2000. do 20Io. (Europska komisija, 20IIa; 20IIb). Međutim, svakako je važno naglasiti da stvarne i ukupne učinke na hrvatski proračun nije moguće točno i u potpunosti procijeniti jer ovise o velikom broju internih i eksternih faktora. Stoga analiza $u$ ovom radu može poslužiti tek kao uvid u red veličine i očekivani smjer učinaka pristupanja te zbog toga navedene rezultate valja interpretirati s određenom dozom opreza.

Nakon uvodnog dijela rada slijedi prikaz postojećeg sustava prihoda i rashoda proračuna EU. Obzirom da se od 20I4-2020. predviđaju značajne promjene u financiranju EU proračuna, baš kao i financiranju iz proračuna EU, treći dio rada dat će sažeti prikaz predloženih reformi u sklopu višegodišnjeg financijskog okvira. Četvrti dio rada bavit će se kvalitativnim i kvantitativnim procjenama neto učinka pristupanja Hrvatske Europskoj uniji u 20I3., a u petom dijelu će se prikazati srednjoročna perspektiva Hrvatske od 2014. do 2020. temeljem iskustava novih zemalja članica i javno dostupnih informacija o potencijalnim novčanim tokovima iz EU proračuna. Nakon toga slijedi zaključak rada.

\section{POSTOJEǴI SUSTAV PRIHODA I RASHODA PRORAČUNA EU}

Po pristupanju u EU dolazi do značajnih promjena u strukturi proračunskih prihoda i rashoda, budući da se dio proračunskih prihoda zemalja članica standardnim mehanizmima odljeva u proračun EU, a istodobno se pojavljuju neke nove kategorije prihoda i rashoda u proračunima zemalja članica ${ }^{2}$. U nastavku će biti dana sinteza glavnih aktualnih kategorija prihoda i rashoda, a detalji o tim stavkama proračuna mogu se naći u postojećoj literaturi (vidjeti primjerice Kandžija i Cvečić, 20II; Europska komisija, 20IIa; Cuculić, Faulend i Šošić, 2004; Sopek, 20II). Ovaj sustav kategorija prihoda i rashoda važeći je još samo do kraja 20I3., odnosno za Hrvatsku će vrijediti samo u prvih pola godine članstva. U novoj financijskoj perspektivi koja pokriva razdoblje od 20I4. do 202O. predlažu se određene izmjene u pojedinim kategorijama prihoda i rashoda, a o čemu će biti više riječi u trećem poglavlju. Međutim, financijska perspektiva za razdoblje 20I4-2020. još uvijek nije prihvaćena te je neizvjesno hoće li zaista doći do navedenih promjena.

Prije, ali i nakon pristupanja EU zemlje pristupnice dužne su uskladiti porezni i carinski sustav sa standardima EU, što svakako dovodi do pozitivnih (povećanje proračunskih prihoda zemlje članice) ili negativnih (smanjenje proračunskih prihoda zemlje članice) učinaka za proračun, a ovisno o stupnju

\footnotetext{
${ }^{\mathrm{I}} \mathrm{U}$ cijelom radu će se zbog jednostavnosti koristiti pojam proračun koji u svakom kontekstu podrazumijeva proračun opće države, osim ako nije eksplicitno navedeno drugačije.

${ }^{2}$ Prihodi proračuna EU zapravo podrazumijevaju rashode zemalja članica.
} 
usklađenosti zemlje pristupnice, odnosno zemlje članice. Međutim, osim učinaka koje pridruživanje EU ima na postojeće prihode državnog proračuna (carine, PDV, trošarine), pojavljuju se i neke nove kategorije prihoda koje su posljedica transfera iz proračuna EU na osnovi sudjelovanja u zajedničkim politikama EU. Pozitivna strana dobivanja transfera iz proračuna EU očituje se smanjenjem rashoda za financiranje postojećih sustava potpora jer sredstva iz proračuna EU zamjenjuju nacionalno financiranje (učinak supstitucije).

Transferi iz proračuna EU mogu se podijeliti na one koji nisu vezani za projekte pa njihov iznos automatski postaje prihod proračuna zemlje članice te na one koji ovise o projektima pa priljev ovisi o tome kolika je apsorpcijska moć pojedine članice mjerena prvenstveno administrativnim apsorpcijskim kapacitetom kao ključnom odrednicom uspješnosti implementacije strukturnih politika EU te financijskim apsorpcijskim kapacitetom kao mjerom sposobnosti sufinanciranja projekata na državnoj i lokalnoj razini.

U grupu transfera koji nisu vezani uz projekte pripadaju izravne dohodovne potpore, tržišne intervencije u poljoprivredi i transferi po osnovi unutarnjih politika. Potpore poljoprivrednicima koje nisu vezane uz projekte dolaze iz poljoprivrednog fonda, točnije iz njegova dijela za jamstva, i čine važan dio transfera iz EU proračuna, a podrazumijevaju direktne potpore (najveći udio), povrate sredstava za izvoz poljoprivrednih proizvoda $\mathrm{u}$ treće zemlje, interventne mjere reguliranja poljoprivrednih tržišta (vino, voće i povrće, mlijeko, šećer, itd.) i ostalo. Transferi po osnovi unutarnjih politika obuhvaćaju niz programa EU čiji je glavni cilj povećanje suradnje između država članica u provođenju zajedničkih politika, a to su primjerice programi za ulaganje u građanstvo, slobodu, sigurnost, pravdu, obrazovanje, zaštitu okoliša, istraživanje, energetsku učinkovitost i slično. Razlog postojanja ovih programa je taj što EU smatra da je bolje provoditi zajedničke politike putem raznih organizacija, udruženja i pravnih osoba nego isključivo putem tijela javne uprave.

U grupu transfera koji ovise o projektima ubrajaju se transferi iz Strukturnih fondova, Kohezijskog fonda te sredstva za ruralni razvoj. Strukturni fondovi imaju tri glavna cilja: promoviranje razvoja strukturnih prilagodbi regija koje zaostaju u razvoju, ekonomska i socijalna potpora područjima sa strukturnim poteškoćama te potpora adaptaciji i modernizaciji politika i sustava za obrazovanje, trening i zapošljavanje. Strukturnim fondovima pomažu se isključivo regije čiji je BDP manji od 75\% prosjeka Europske unije, a sufinanciraju se projekti do maksimalno 75\% iznosa opravdanih troškova. Korištenje Kohezijskog fonda dozvoljeno je zemljama koje imaju niži bruto nacionalni dohodak od 90\% prosjeka zemalja Unije. Kohezijskim fondom financira se izgradnja transeuropskih transportnih mreža, projekti od posebnog značenja te ostale transportne aktivnosti i aktivnosti vezane za okoliš, a sufinanciraju se projekti do maksimalno 85\% iznosa opravdanih troškova. Sredstva za ruralni razvoj podrazumijevaju financiranje iz Europskog poljoprivrednog fonda za ruralni razvoj odobrena temeljem projektnih planova čime se potiče unaprjeđenje dosljednosti, transparentnosti i jasnoće financiranja ruralnog razvoja.

Osim svega navedenog, postoji i treća skupina transfera iz proračuna EU koja uključuje ostale pretpristupne pomoći, specijalne aranžmane i proračunske kompenzacije, ali u odnosu na prve dvije 
komponente, ova komponenta u ukupnom proračunu EU ima relativno malen utjecaj. Međutim, iako kompenzacije imaju relativno malen udio u ukupnom proračunu EU (I,5\% u 2004., 0,4\% u 2007., a u 20I0. O\%), one su iznimno značajne u alociranim iznosima novih zemalja članica u prvim godinama članstva, a uvedene su kako nove zemlje članice ne bi bile neto uplatiteljice u svojim prvim godinama članstva. Tako primjerice u 2004. kompenzacije imaju prosječan udio od 35\% ukupnog iznosa alociranih sredstava, pri čemu je to $73 \%$ u slučaju Cipra, 70\% Malte, 41\% Češke, 37\% Slovenije, itd. Ukoliko se tome dodaju još i ostale pretpristupne pomoći, te dvije komponente zajedno čine prosječno 55\% ukupnih alociranih sredstava novih zemalja članica u 2004. (Europska komisija, 20IIb).

Osim navedenih stavki koje utječu na prihodovnu stranu proračuna (a neke od njih istovremeno i na rashodovnu stranu zbog potrebe sufinanciranja projekta), postoje i nove kategorije rashoda zemalja članica EU. Vlastiti prihodi EU proračuna predstavljaju sredstva koja se automatski transferiraju iz proračuna zemalja članica u proračun EU prema unaprijed zadanim ključevima i za koje ne treba posebna odluka nacionalnih vlasti. Vlastiti prihodi proračuna EU dijele se na tri glavne komponente, a to su tradicionalni vlastiti prihodi (Traditional Own Resources - TOR), prihodi na temelju poreza na dodanu vrijednost (PDV) i prihodi na temelju bruto nacionalnog dohotka (BND). Poseban dio EU vlastitih prihoda predstavljaju i razne korekcije, od čega je najznačajnija korekcija za Veliku Britaniju³.

Tradicionalni vlastiti prihodi obuhvaćaju carine, poljoprivredne carine i namete na šećer pri čemu se $75 \%$ svih takvih prikupljenih prihoda automatski transferira u proračun EU, dok ostatak od $25 \%$ zadržava zemlja članica za namirenje troškova njihovog prikupljanja ${ }^{4}$. Stoga možemo konstatirati da je gubitak državnog proračuna za prihode od carina dvojak, jer obuhvaća izravni gubitak zbog automatskog transfera u proračun EU i neizravni gubitak zbog usklađivanja s carinskom tarifnom strukturom EU.

Prihodi na temelju PDV-a računaju se kao određeni postotak osnovica PDV-a, koje moraju biti usklađene s pravilima EU. Ipak, da bi se spriječilo neproporcionalno uplaćivanje u proračun EU, osnovica PDV-a je ograničena s 50\% bruto nacionalnog dohotka ${ }^{5}$. Međutim, iako je neproporcionalno uplaćivanje po osnovi PDV-a donekle ublaženo, ono nije u potpunosti eliminirano. Prema Europskoj komisiji (20IIg), osnovica PDV-a nije proporcionalna BND-u zemalja članica te se na neke od najbogatijih članica EU poput Luksemburga i (u manjoj mjeri) Irske također primjenjuje navedeno ograničenje od 50\% BND-a čime se smanjuje njihov doprinos proračunu EU. Od I. siječnja 2007. primjenjuje se uniformna stopa od o,3\% na osnovicu PDV-a, odnosno na 50\% bruto nacionalnog dohotka, pri čemu su definirane iznimke od tog pravila za Austriju (o,225\%), Njemačku (o,I5\%), Nizozemsku (o,I\%) i Švedsku (o,I\%).

\footnotetext{
${ }^{3}$ Osim korekcije za Veliku Britaniju, postoje korekcije i za ostale najveće neto uplatitelje - Austriju, Njemačku, Nizozemsku i Švedsku. Te se korekcije u tekstu razmatraju u okviru pojedine komponente prihoda proračuna EU na koje se primjenjuju (unutar korekcije za Veliku Britaniju, prihoda na temelju PDV-a i BND-a).

${ }^{4}$ Budući da zadržavanje udjela od $25 \%$ ukupnog iznosa tradicionalnih vlastitih prihoda prikupljenih od zemalja članica premašuje stvarne troškove troškova njihova prikupljanja, ovaj model sadrži određeni skriveni korekcijski mehanizam (Europska komisija, 2OIIg).

${ }^{5}$ Ukoliko osnovica PDV-a pojedine zemlje prelazi 50\% BND-a, primjenjuje se stopa od o,3\% na 50\% BND-a. To ograničenje uvedeno je zbog toga što se pokazalo da kod manje prosperitetnih zemalja potrošnja, a samim time i osnovica PDV-a, bilježe više udjele u BND-u. Bez navedenog ograničenja relativno slabije razvijene zemlje uplaćivale bi neproporcionalno velike iznose u EU proračun u odnosu na njihov stvarni kapacitet (Europska komisija, 20IIa).
} 
Prihodi na temelju bruto nacionalnog dohotka svakako su najveći teret za državni proračun zemalja članica EU. Ukupan prihod proračuna EU-a po osnovi BND-a izračunava se kao razlika ukupnih rashoda proračuna EU-a i prihoda skupljenih po ostalim osnovama. Drugim riječima, taj prihod "krpa" rupe u proračunu EU i svaka država članica uplaćuje svoj dio na osnovi relativne veličine vlastitog BND-a. Nizozemskoj i Švedskoj je odobrena posebna pogodnost paušalnog umanjenja prihoda na temelju BND-a koja iznosi 605 mil. EUR godišnje za Nizozemsku i I5o mil. EUR godišnje za Švedsku obračunato u stalnim cijenama iz 2004.

Dodatni trošak za proračun zemlje članice predstavlja i uplata za korekciju za Veliku Britaniju (UK correction). Naime, Velika Britanija je nakon pristupanja EU postala najveći neto uplatitelj u proračun, ponajviše zahvaljujući niskoj razini transfera iz Zajedničke poljoprivredne politike (ZPP) zbog svog relativno malog poljoprivrednog sektora. Zbog toga se od 1985. godine Velikoj Britaniji svake godine vrati dio uplate $\mathrm{u}$ proračun $\mathrm{u}$ iznosu od $66 \%$ njezine neto pozicije. Gubitak tih prihoda zajednički nadoknađuju ostale države članice, s time da Njemačka, Nizozemska, Austrija i Švedska (najveći neto uplatitelji) snose samo jednu četvrtinu udjela.

\section{GRAFIKON I.}

Rashodi EU proračuna po glavnim kategorijama u razdoblju 2007-20Io., mlrd. EUR

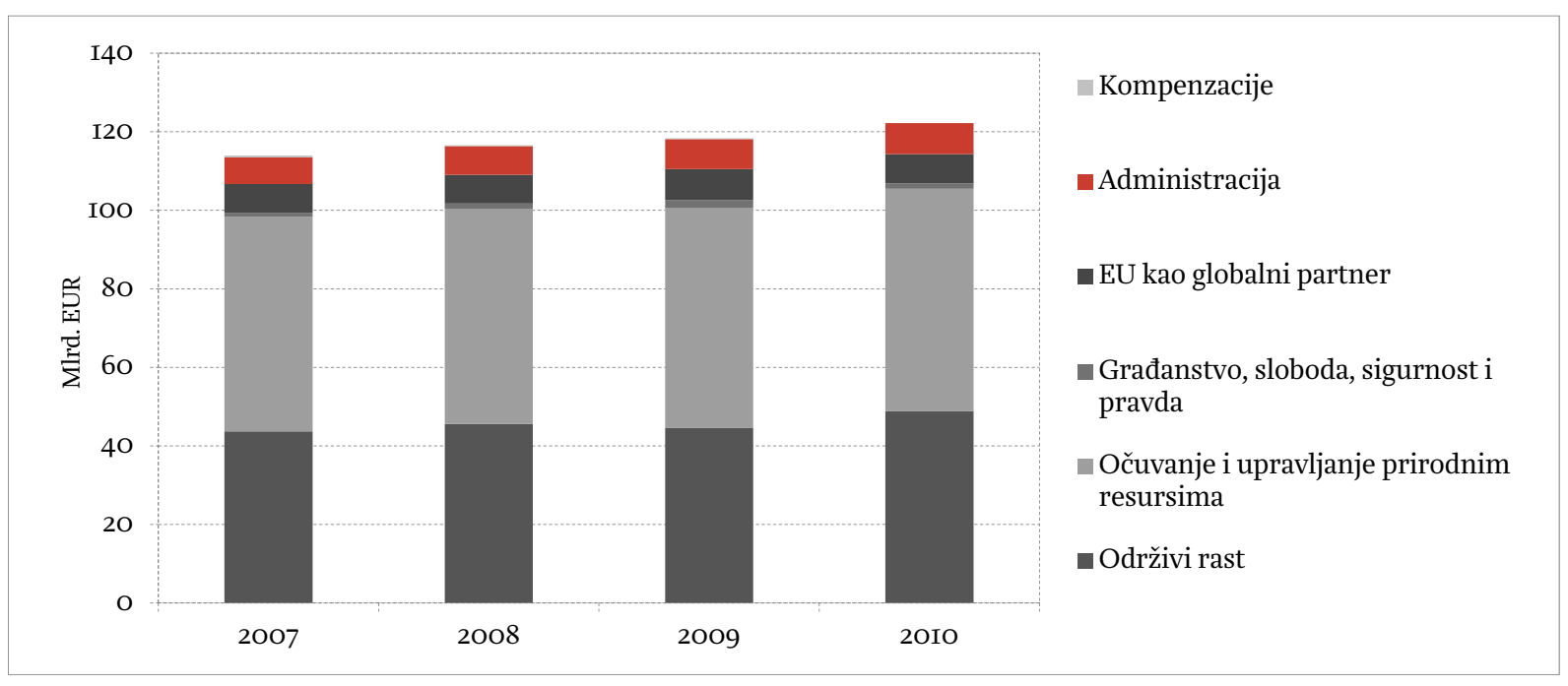

Izvor: izračun autora temeljem Europske komisije (20IIb).

Ukupni rashodi EU proračuna u 20IO. iznosili su I22 mlrd. EUR. Od toga se najveći dio odnosi na kategorije očuvanje i upravljanje prirodnim resursima (46\%) i održivi rast (40\%). Manje udjele u ukupnim rashodima čine kategorije EU kao globalni partner (6\%) i Administracija (6\%). Očuvanje i upravljanje prirodnim resursima uključuje $u$ najvećoj mjeri izravne potpore $\mathrm{i}$ intervencije $\mathrm{u}$ poljoprivredi (78\%) te sredstva za ruralni razvoj (20\%). Skupinu održivog rasta čine dvije kategorije. Prva je kohezija za rast i zapošljavanje koja čini $76 \%$ sredstava skupine održivog rasta, a u nju ulaze Strukturni fondovi (79\% sredstava iz kategorije kohezija za rast i zapošljavanje) i Kohezijski fond (21\%). Druga kategorija skupine održivog rasta je konkurentnost za rast i zapošljavanje s udjelom od 24\%, a u tu kategoriju ulaze razni programi za poticanje istraživanja, inovativnosti, cjeloživotnog učenja i razvoja socijalnih politika. Rashodi EU proračuna bilježe trend povećanja iz godine u godinu. U odnosu 
na 2007. ukupni rashodi u 20IO. veći su za 7\%, u odnosu na 2004. 22\%, a u odnosu na 2000. čak 46\%. Najveći porast od čak II\% na godišnjoj razini zabilježen je u 2004. prvenstveno zbog uključivanja novih zemalja članica. Najveći dio sredstava iz EU proračuna u 20IO. dodijeljen je Španjolskoj (Io,8\%), Francuskoj (IO,7\%), Njemačkoj (9,7\%) i Poljskoj (9,7\%). Međutim, ukoliko se analizira iznos uplaćenih sredstava iz EU proračuna u odnosu na BND zemalja članica, najveće udjele u 20Io. dobile su Litva (5,9\%), Estonija (5,8\%), Luksemburg (5,2\%) i Latvija (4,6\%).

\section{GRAFIKON 2.}

Prihodi EU proračuna po glavnim kategorijama u razdoblju 2007-20IO., mlrd. EUR

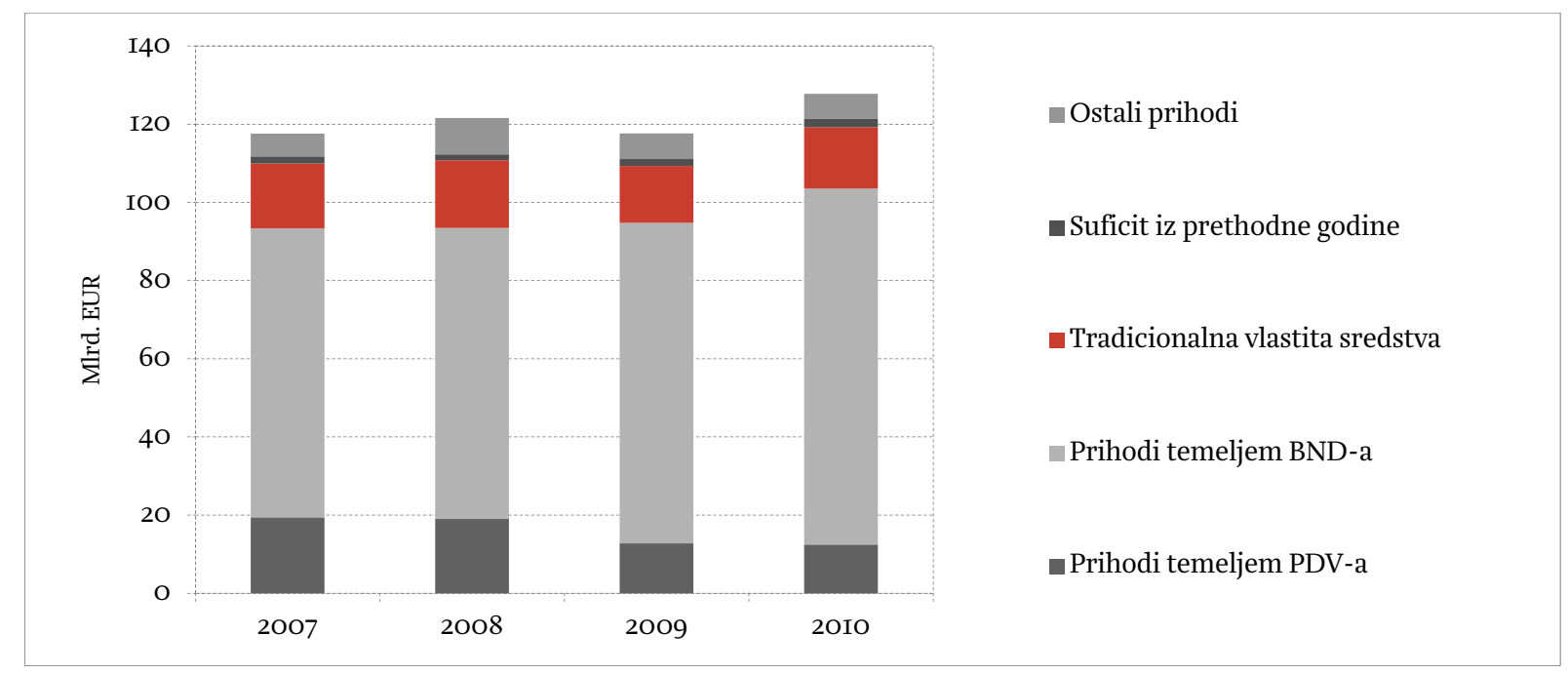

Izvor: izračun autora temeljem Europske komisije (20IIb).

Ukupni prihodi EU proračuna u 20IO. iznosili su I28 mlrd. EUR, od čega najveći dio čine prihodi temeljem BND-a (7I\%). Tradicionalna vlastita sredstva čine tek 12\% ukupnih prihoda EU proračuna, a prihodi temeljem PDV-a IO\%. Razne korekcije koje čine značajne udjele u proračunima zemalja članica, u ukupnom proračunu EU nisu signifikantne, budući da se navodi samo njihova neto pozicija (uplate zemalja članica umanjene za isplate, prvenstveno Velikoj Britaniji). Za razliku od rashoda koji su konstantno bilježili trend rasta, kod prihoda EU proračuna je situacija ponešto drugačija, prvenstveno zbog pojave globalne krize. Utjecaj krize se najbolje vidi u 2009. u odnosu na 2008. budući da su prihodi temeljeni na PDV-u na godišnjoj razini pali za 33\%, a tradicionalni vlastiti prihodi za 16\%. Shodno tome, morali su se povećati prihodi temeljeni na BND-u i to za IO\%. Najveće uplatiteljice sredstava u EU proračun u 20IO. bile su Njemačka (20,0\%), Francuska (I6,4\%), Italija (I2,9\%) i Velika Britanija (I2,3\%) ${ }^{6}$. U odnosu na BND zemlje članice, najveća uplatiteljica u 20Io. bila je Belgija s I,34\% BND-a.

\section{NOVA FINANGIJSKA PERSPEKTIVA EU OD 20I4-2020.}

Za razdoblje od 2014-2020. predviđena je nova financijska perspektiva EU opisana u višegodišnjem financijskom okviru naziva “A Budget for Europe 2020" (Europska komisija, 2OIId; 20IIe) i čitavom nizu dodataka i nadopuna tog dokumenta (vidjeti primjerice Europska komisija, 20IIf; 20IIg). Ovim se dokumentima predlažu brojne promjene $u$ financiranju i izdacima proračuna EU. Glavne promjene $u$

\footnotetext{
${ }^{6}$ Bez korekcije, udio Velike Britanije iznosio bi 15,3\% ukupnih uplata u EU proračun.
} 
razdoblju od 20I4. do 2020. koje nosi prijedlog nove financijske perspektive, aktualan u trenutku pisanja rada, bit će navedene u nastavku. Međutim, vrlo je neizvjesno, a za neke prijedloge čak i malo vjerojatno, da će u konačnici biti usvojene i da će se primjenjivati u novoj financijskoj perspektivi.

\section{I. PREDLOŽEne PROMJENE U PRIHODima PRORAČUNA EU}

U financiranju proračuna EU u razdoblju 20I4-2020. predlaže se reforma vlastitih sredstava kojom bi se značajnije izmijenio sustav postojećih prihoda proračuna EU temeljenih na PDV-u, a stvorile bi se nove vrste prihoda temeljene na oporezivanju financijskih transakcija. Svrha uvođenja novih vlastitih prihoda EU nije povećanje ukupnog europskog proračuna, nego doprinos naporima konsolidacije proračuna zemalja članica, budući da bi ti prihodi EU proračuna doveli do reduciranja direktnih plaćanja iz proračuna zemalja članica. Predložene promjene će također pojednostaviti postojeće doprinose zemalja članica proračunu EU te integrirati EU politike i EU financiranje (Europska komisija, 2OIIh).

Oporezivanje financijskog sektora značilo bi jedan sasvim novi oblik prihoda za EU proračun, čime bi se potencijalno umanjili postojeći doprinosi zemalja članica. To bi svakako ostavilo više manevarskog prostora nacionalnim vlastima, ali bi pomoglo i u provođenju proračunskih konsolidacija. Porez na financijske transakcije koji bi se prikupljao na razini EU također bi umanjio probleme tzv. poštenog povrata koji se mogu uočiti u postojećem financijskom sustavu, a inicijativa EU za uvođenje oporezivanja financijskih transakcija predstavljala bi i prvi korak $\mathrm{u}$ primjeni takvog modela oporezivanja na globalnoj razini. Model oporezivanja financijskih transakcija kojeg predlaže Europska komisija sastojao bi se od dvije različite stope, pri čemu bi se trgovina dionicama, obveznicama i ostalim sličnim vrijednosnicama oporezivala po stopi od o,I\%, dok bi se na trgovinu ostalim financijskim instrumentima (izvedenicama) primjenjivala stopa od o,oı\% (Europska komisija, 20IIg). Prijedlogom je zamišljeno da se dvije trećine budućeg poreza na financijske transakcije iskoristi za financiranje proračuna EU, dok bi se ostatak slijevao u proračune pojedinih članica (Europska komisija, 20IIj). Upravo ovaj porez potiče brojne rasprave i nesuglasice među zemljama članicama pa je njegova konačna primjena još uvijek upitna, budući da je za prihvaćanje takvog model oporezivanja potreban konsenzus zemalja članica.

Najveći protivnik uvođenja poreza na financijske transakcije je Velika Britanija čiji Gornji dom u svom izvješću tvrdi da bi taj porez doveo do bijega kapitala izvan EU. Eventualna sugestija je da se takav porez primjenjuje isključivo unutar ili tek u pojedinim zemljama Euro zone (House of Lords, 20I2). Unutar EU najveći protivnik uvođenja poreza na financijske transakcije je i Švedska, koja je I984. samostalno uvela sličan porez što se nije pokazalo uspješnim te ga je 199ı. i ukinula. Osim Velike Britanije i Švedske, Luksemburg, Nizozemska i Malta također se zalažu za odbijanje prijedloga za uvođenje poreza na financijske transakcije. Irska pak se navedenom prijedlogu protivi ukoliko bi se primjenjivao na samo neke članice EU. S druge strane, najveći zagovornici uvođenja tog poreza su Njemačka i Francuska, ističući da bi se tim porezom raspodijelio teret krize i na financijske institucije, a njime bi se također 
mogle financirati i posrnule banke. Osim Njemačke i Francuske, pozitivno su opredijeljene glede uvođenja tog poreza još i Austrija, Belgija, Portugal, Slovenija, Španjolska, Grčka, Slovačka i Estonija.

Za izračun novih sredstava EU proračuna temeljem PDV-a odabrana je jednostavna metoda kojom se u proračun EU transferira određeni udio sredstava koje prikupe nacionalne porezne vlasti. Naime, iz dijela prikupljenih prihoda od PDV-a porezne vlasti bi izdvojile one prihode koji su dobiveni oporezivanjem dobara i usluga uz primjenu standardne stope PDV-a te bi na taj iznos primijenile definiranu EU stopu da bi se dobio konačan iznos koji će se transferirati u EU proračun. Za razliku od postojećih prihoda EU proračuna na temelju PDV-a, kod kojih se do teoretske osnovice PDV-a dolazi kompleksnim statističkim izračunima i prilagodbama, ovako definirani prihodi značajno pojednostavljuju izračun. Nadalje, ovakav sustav bi povezao EU politiku oporezivanja dodane vrijednosti s EU proračunskim politikama (Europska komisija, 20IIg). Prihodi EU proračuna rasli bi u slučaju širenja nacionalne osnovice PDV-a, do čega može doći ili zbog povećanja liste oporezivih dobara i usluga, odnosno smanjenja izuzeća u sustavu PDV-a, ili zbog povećanja potrošnje. Također, do povećanja prihoda EU proračuna došlo bi i umanjivanjem obuhvata isporuka oporezivanih nultom ili sniženim stopama, budući da bi se na te isporuke dobara i usluga tada primijenila standardna stopa PDV-a te bi u tom slučaju ti prihodi od PDV-a ušli u obuhvat primjene stope za transfer u EU proračun. Prema Europskoj komisiji (20IIi) primijenjena stopa ne bi smjela prelaziti 2\%, a predlaže se primjena stope od I\% na neto vrijednost isporuka dobara i usluga koje se oporezuju standardnom stopom (Europska komisija, 20IIj). Grafikon 3. prikazuje ostvarene prihode temeljem PDV-a (\% BND-a) u odnosu na BDP po stanovniku PPS u 20o9. i procijenjene prihode sukladno novom prijedlogu EU proračuna.

\section{GRAFIKON 3.}

Ostvareni prihodi temeljem PDV-a (\% BND-a) u odnosu na BDP po stanovniku PPS u 2009. i procijenjeni prihodi sukladno novom prijedlogu EU proračuna

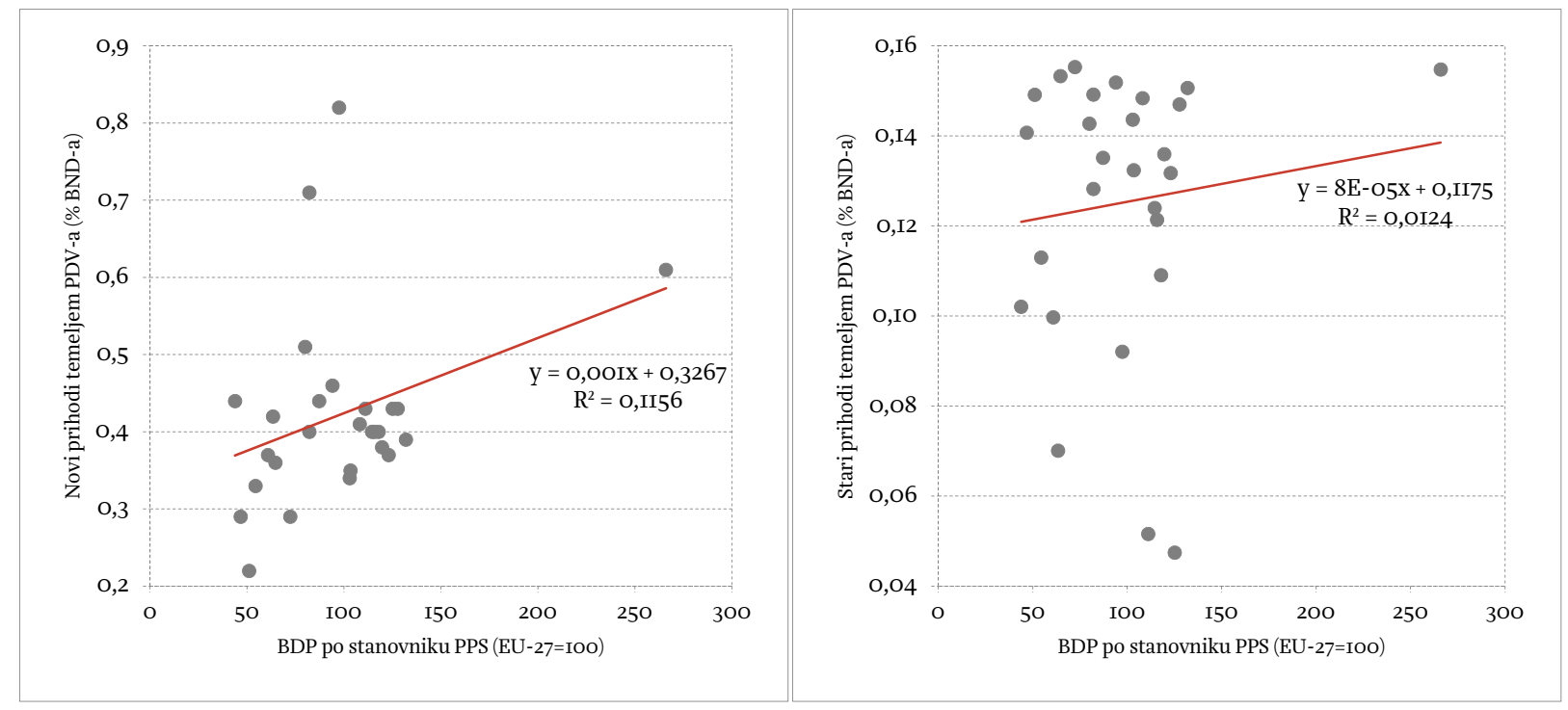

Izvor: izračun autora temeljem Europske komisije (20IIb, 20IIl) i Eurostata. 
Grube procjene Europske komisije (20IIl) pokazuju da bi Cipar, Malta i Luksemburg trebale imati više udjele prihoda temeljem PDV-a u BND-u od prosjeka, dok bi Latvija, Slovačka i Rumunjska imale niže udjele. Grafikon 3. prikazuje da bi se uvođenjem novih prihoda od PDV-a samo djelomično uspjelo ublažiti neproporcionalno uplaćivanje u proračun EU u odnosu na razvijenost zemlje članice. I dok bi prosječno povećanje prihoda temeljem PDV-a u odnosu na sadašnji model na razini EU-27 trebalo iznositi $267 \%$, najveće povećanje procijenjeno je u Nizozemskoj i iznosi čak 722\% (s 0,05\% na 0,39\% BND-a). Budući da postoji snažna korelacija između osnovice PDV-a i BND-a, može se očekivati da bi novi prihodi temeljem PDV-a bili stabilan i značajan prihod za proračun EU te bi se uglavnom kretali u skladu s BND-om zemalja članica (Europska komisija, 20IIl).

Osim navedenih novih kategorija prihoda proračuna EU, inicirane su i neke promjene u postojećim prihodima koje se tiču prvenstveno pojednostavljivanja korekcijskih mehanizama zamjenom dosadašnjeg kompleksnog sustava korekcija jednostavnim sustavom putem paušalnih iznosa određenih u odnosu na BND kontribuciju pojedine zemlje članice. Predložena reforma se temelji na tzv. Fontainebleu-ovom principu iz 1984., prema kojem svaka zemlja članica koja podnosi proračunski teret nerazmjeran njenom relativnom prosperitetu može to nadoknaditi korekcijama $u$ određenom trenutku (Europska komisija, 20IIh). Osim promjena u korekcijama mijenja se i politika tradicionalnih vlastitih prihoda. Budući da se novom financijskom perspektivom predlaže određivanje svota korekcijskih mehanizama $u$ paušalnim iznosima, udio zadržavanja tradicionalnih vlastitih prihoda trebao bi biti ograničen s Io\%, umjesto s 25\%, što je ujedno i u skladu sa sustavom koji se primjenjivao do 200o. (Europska komisija, 20I1i).

Tablica I.

Procijenjene promjene u strukturi financiranja proračuna EU (mlrd. EUR i \% vlastitih prihoda)

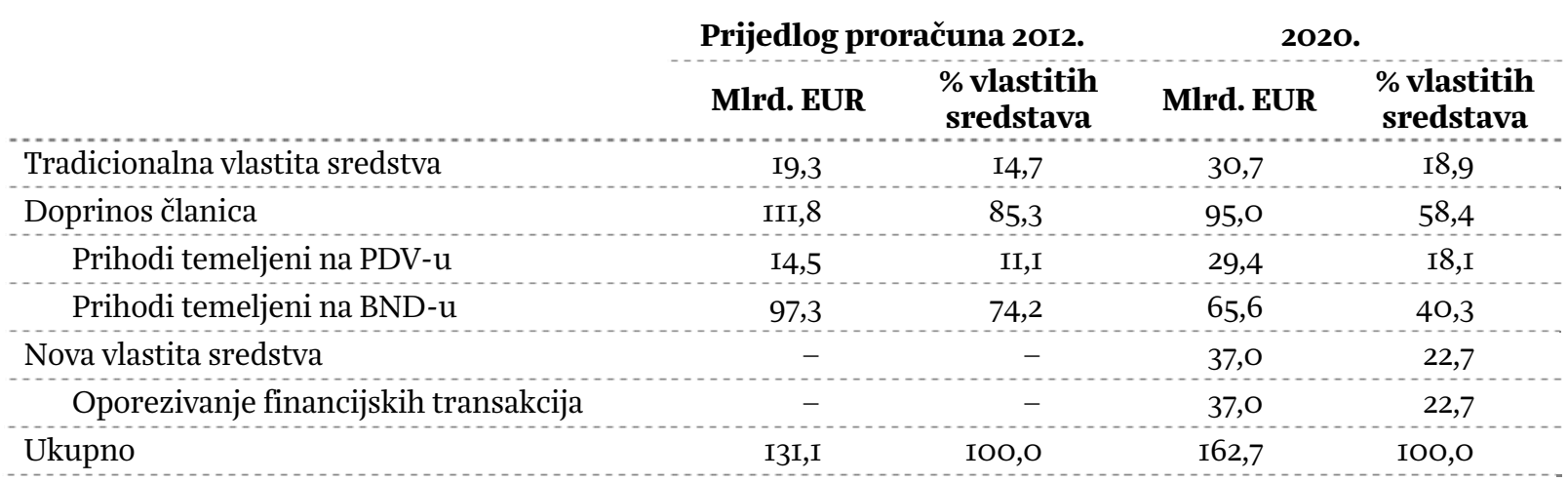

Izvor: Europska komisija (20IIk); prilagodba autora.

Prema procjenama Europske komisije (20IIk), novim prijedlozima financiranja proračuna EU značajno bi se promijenila struktura prihoda. Za razliku od dosadašnjeg modela $u$ kojem je većina prihoda transferirana u proračun EU temeljem BND-a zemalja (prihodi na temelju BND-a i djelomično prihodi na temelju PDV-a), novim sustavom bi se doprinos zemalja članica temeljen na BND-u smanjio na 40ak posto. Oporezivanje financijskih transakcija činilo bi gotovo četvrtinu prihoda proračuna EU. Također, u ukupnoj strukturi prihoda povećao bi se i doprinos tradicionalnih vlastitih sredstava s 
nepunih I5\% na $19 \%$ (povećanje za 29\%) te doprinos prihoda temeljenih na PDV-u s II\% na $18 \%$ (povećanje za 63\%).

\subsection{PREDloŽENE PROMJENE U RASHOdima PRORAČUNA EU}

Stavke rashoda EU prijedloga proračuna usporedno su iskazane na dva načina, odnosno prikazuju zasebno rashode prema obračunskom načelu (commitment appropriations) i rashode prema gotovinskom načelu (payment appropriations). Razlog ovakvog iskazivanja proračunskog planiranja jest u tome da se sve veći dio rashoda odnosi na višegodišnje projekte pa se plaćanja uobičajeno vrše tijekom nekoliko godina. Stoga rashodi prema obračunskom načelu predstavljaju troškove koji proizlaze iz aktivnosti izvedenih (obračunatih, fakturiranih) tijekom pojedine financijske godine. S druge strane, rashodi prema gotovinskom načelu obuhvaćaju iznose plaćanja za aktivnosti izvedene te godine i sva plaćanja po osnovi obveza iz prethodnih razdoblja, ali ne uključuju iznose koji se odnose na tu godinu, a na naplatu dospijevaju u nekim kasnijim razdobljima.

Prema podacima Europske komisije (20IIh), nominalni iznos ukupnih rashoda proračuna EU prema obračunskom načelu za razdoblje 20I4-202O. (I.025 mlrd. EUR) viši je za otprilike 3\% u odnosu na rashode predviđene u razdoblju 2007-2013. (994 mlrd. EUR). U odnosu na BND, ukupan iznos rashoda EU proračuna prema obračunskom načelu za razdoblje 20I4-2020. smanjuje se na razinu od I,O5\%, u odnosu na I,I2\% BND-a u razdoblju 2007-20I3.

S druge strane, nominalni iznos ukupnih rashoda proračuna EU prema gotovinskom načelu za razdoblje 2OI4-2O2O. (972 mlrd. EUR) također je viši za otprilike 3\% u odnosu na rashode predviđene u razdoblju 2007-2013. (943 mlrd. EUR). U odnosu na BND, ukupan iznos rashoda EU proračuna prema obračunskom načelu za razdoblje 20I4-2020. smanjuje se na razinu od 1,00\%, u odnosu na I,o6\% BNDa u razdoblju 2007-2013.

Svakako, jedna novost je i da Europska komisija po prvi puta prikazuje i konsolidirane rashode za razdoblje 20I4-2020. zajedno s višegodišnjim financijskim okvirom, što ukupno iznosi I,II\% BND-a Europske unije (CPMR, 2OII). Konsolidirani rashodi podrazumijevaju sve fleksibilne rashode koji se tradicionalno vode izvan višegodišnjeg financijskog okvira budući da nisu programibilni. U tu se kategoriju ubrajaju Rezerve za hitnu pomoć (Emergency Aid Reserve), Europski fond za prilagodbu globalizaciji (European Globalisation Adjustment Fund), Fond solidarnosti (Solidarity Fund), Fleksibilni instrument (Flexibility Instrument), itd. Međutim, ukoliko u slučaju nužde proračunske vlasti odluče aktivirati dodatne fondove, oni ulaze u godišnji proračun EU (Europska komisija, 2OIIh).

Struktura rashoda proračuna EU u razdoblju 2007-20I3. te u novoj financijskoj perspektivi od 20I4. do 2020. prikazana je na grafikonu 4. 


\section{GRAFIKON 4.}

Struktura rashoda EU proračuna po glavnim kategorijama u razdoblju 2007-2013. i 2014-2O2O. (u \%)

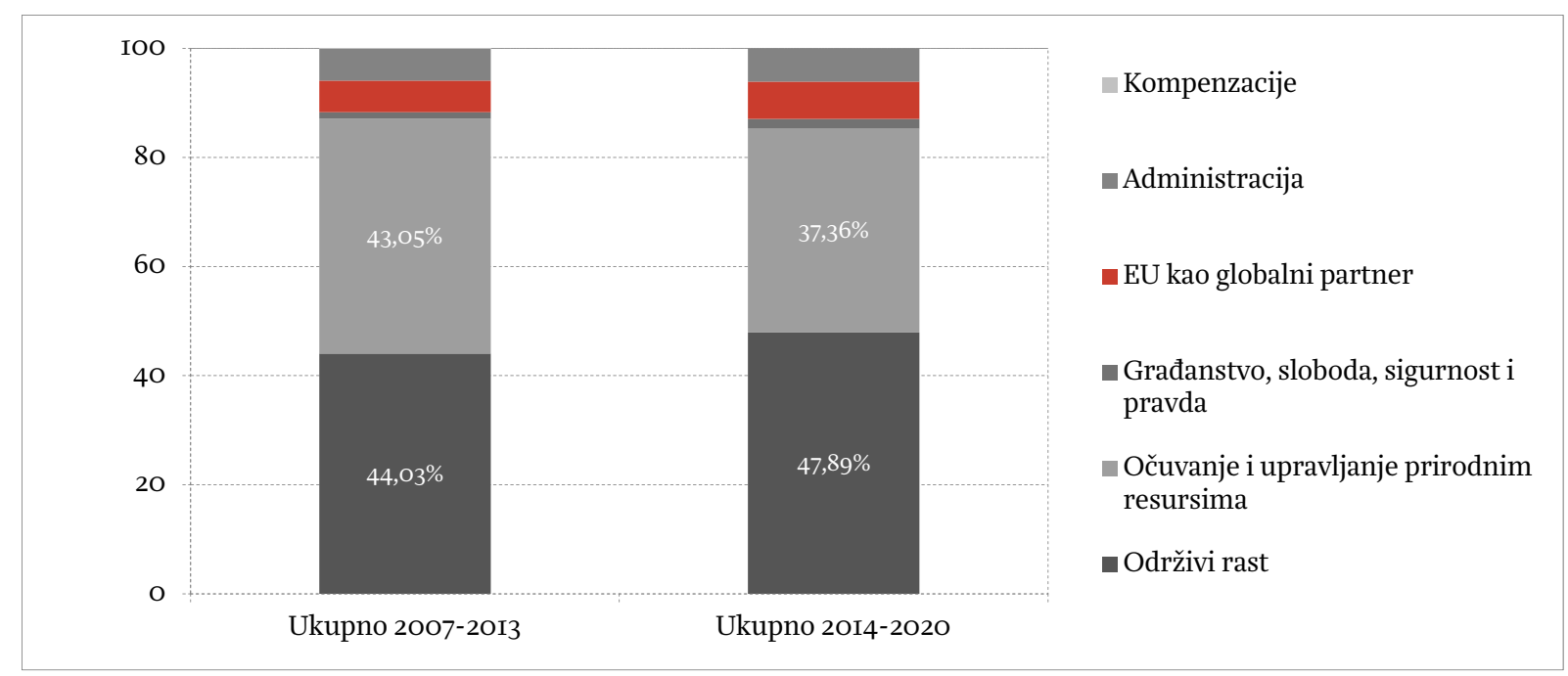

Izvor: izračun autora temeljem Council of the EU (2005) i Europske komisije (20IIh).

U ukupnim rashodima EU proračuna kategorije održivi rast te očuvanje i upravljanje prirodnim resursima čine preko pet šestina ukupnog proračuna, odnosno $87 \%$ u razdoblju 2007-2013. te $85 \%$ u razdoblju 20I4-2020. Manje udjele u ukupnim rashodima čine kategorije EU kao globalni partner (67\%) i Administracija (6\%). U odnosu na financijsku perspektivu 2007-2013., u novoj financijskoj perspektivi 20I4-2020. predlažu se određene promjene u strukturi rashoda, odnosno u kategoriji održivi rast predlaže se povećanje s $44 \%$ na $48 \%$ ukupnih rashoda, a u kategoriji očuvanje i upravljanje prirodnim resursima predlaže se smanjenje s $43 \%$ na 37\% ukupnih rashoda.

Generalno, u razdoblju 20I4-2020. Zajednička poljoprivredna politika (Common Agricultural Policy) i kohezijska politika ostaju i dalje glavne stavke EU proračuna (36,3\% za ZPP i 32,8\% za koheziju), ali su proračunski iznosi za te stavke smanjeni za I6,4\% te preusmjereni na stavke Istraživanje, razvoj i inovacije (porast od 35\%) te Vanjsku pomoć koja je povećana za 25\% (CPMR, 2OII).

Kohezijska politika će i dalje biti koncentrirana na slabije razvijene regije i zemlje članice s prosjekom BDP-a po stanovniku ispod 75\% europskog prosjeka (konvergencijske regije). Smanjenje proračuna za kohezijske politike može se djelomično objasniti činjenicom da su pojedine zemlje izašle iz opsega financiranja pod ovom kategorijom. U okviru kohezijske politike planira se uspostavljanje nove kategorije (tzv. tranzicijske regije) koja će obuhvaćati sve one regije s BDP-om po stanovniku između 75 i 90\% europskog prosjeka, a unutar te kategorije predviđeno je daljnje financiranje zemalja koje izlaze iz opsega financiranja u okviru konvergencijskih regija. Svrha toga je nastavak poticanja razvoja tih zemalja i to u opsegu od dvije trećine dosadašnjih alociranih sredstava (CPMR, 2OII). Tu su još i tzv. konkurentske regije obuhvaćene programom Regionalna konkurentnost i zapošljavanje koje imaju prosjek BDP-a po stanovniku od najmanje $75 \%$ europskog prosjeka. Iznos na koji ostvaruju pravo ovisi o njihovoj stopi nezaposlenosti, zaposlenosti u manje perspektivnim gospodarskim sektorima, razini obrazovanosti, gustoći naseljenosti, itd. (Kandžija i Cvečić, 20II). Prema prijedlogu Europske komisije 
(2OIId), sredstva kohezijske politike u ukupnom iznosu od 376 mlrd. EUR, koja uključuju Strukturne i Kohezijski fond, bit će alocirana na sljedeće segmente:

- I62,6 mlrd. EUR (43\%) za konvergencijske regije;

- $\quad 38,9$ mlrd. EUR (IO\%) za tranzicijske regije;

- 53,I mlrd. EUR (I4\%) za konkurentske regije;

- II,7 mlrd. EUR (3\%) za teritorijalnu suradnju;

- $\quad 68,7$ mlrd. EUR (I8\%) za Kohezijski fond.

Osim toga, 40 mlrd. EUR (II\%) će biti alocirano za povezivanje Europe (Connecting Europe Facility) i to u sljedećim iznosima: 9,I mlrd. EUR za energetski sektor, 2I,6 mlrd. EUR za transport (uključujući dodatnih Io mlrd. EUR koji će biti osigurani unutar Kohezijskog fonda) te 9,I mlrd. EUR za informacijske i komunikacijske tehnologije.

Kašnjenja u pripremi projekata i povezanim aktivnostima dovela su do značajne zalihe neiskorištenih sredstava na kraju trenutnog razdoblja financiranja, a teška fiskalna situacija u pojedinim zemljama članicama otežava osiguravanje sredstava za nacionalno sufinanciranje. Budući da se pokazalo da je većina zemalja imala poteškoća $\mathrm{u}$ apsorbiranju velikih količina sredstava iz EU fondova, Europska komisija (20IId) predlaže sljedeće tri mjere koje će se odnositi na kohezijsku politiku:

- fiksiranje maksimalnih alociranih sredstava na 2,5\% BND-a;

- omogućavanje privremenog povećanja stope sufinanciranja od strane EU (odnosno smanjenje nacionalne stope sufinanciranja) za 5 do Io postotnih bodova;

- uključivanje određenih uvjeta povezanih s jačanjem administrativnih kapaciteta u ugovore o partnerstvu.

Zajednička poljoprivredna politika obuhvaća dva stupa, a to su tržišne mjere poljoprivrednicima (prvi stup) i sredstva za ruralni razvoj (drugi stup). Novi prijedlog Europske komisije (2OIId) predlaže da ZPP u novoj financijskoj perspektivi sadrži "zeleniji” i uniformno distribuirani prvi stup te drugi stup više fokusiran na konkurentnost, inovacije, klimatske promjene i okoliš. $\mathrm{U}$ tu bi svrhu bilo ukupno alocirano 28I,8 mlrd. EUR za prvi stup te 89,9 mlrd. EUR za drugi stup za čitavo razdoblje 20I4-202O.

Novom Zajedničkom poljoprivrednom politikom uvode se tri noviteta, a to su:

- Ozelenjivanje direktnih potpora koje podrazumijeva uvjetovanje direktnih potpora poljoprivrednicima u iznosu od 30\% u svrhu postizanja okolišnih i klimatskih ciljeva u skladu s najboljom praksom očuvanja okoliša. To znači da će se svi poljoprivrednici morati uključiti u razne prakse očuvanja okoliša koje će biti zakonski definirane i dokazive. Na taj bi se način značajno potaknulo pomicanje poljoprivrednog sektora u smjeru održivog razvoja.

- Konvergencija plaćanja kojom bi se razina direktnih potpora progresivno prilagodila u ovisnosti o veličini poljoprivrednog zemljišta (vodeći računa o razlikama u razini plaća i ulaznim troškovima), a u svrhu osiguravanja jednolike distribucije tih potpora među europskim poljoprivrednicima. To bi se postiglo na način da se u planiranom razdoblju svim zemljama članicama s izravnim potporama manjim od 9o\% prosjeka nadoknađuje jedna trećina razlike 
između trenutne i minimalne razine (90\% prosjeka), pri čemu bi tu razliku proporcionalno financirale članice koje primaju nadprosječne izravne potpore.

- Ograničavanje direktnih plaćanja velikim poljoprivrednim imanjima, vodeći računa o ekonomiji razmjera većih struktura i zaposlenosti koje generiraju. Predlaže se da se navedene uštede iskoriste unutar proračunskih alokacija za ruralni razvoj te da se zadrže u nacionalnim omotnicama zemalja članica u kojima su nastale.

Alokacija sredstava za ruralni razvoj trebala bi se temeljiti na objektivnijim kriterijima i bolje ostvarivati ciljeve te politike, što bi trebalo osigurati poštenije tretiranje poljoprivrednika koji se bave sličnim aktivnostima (Europska komisija, 20Irh).

Osim kohezijskih politika obuhvaćenih u kategoriji I. Pametan $i$ uključiv rast te Zajedničkih poljoprivrednih politika u kategoriji II. Održivi rast: prirodni resursi, EU predviđa i izdatke od I5I mlrd. EUR po sljedećim kategorijama:

- Sigurnost i građanstvo - I8,5 mlrd. EUR (2\% ukupnog proračuna EU u razdoblju 2OI4-202O.);

- Globalna Europa - 70,o mlrd. EUR (7\%);

- Administracija - 62,6 mlrd. EUR (6\%).

\section{UǦINGI PRISTUPANJA NA HRVATSKI PRORAǦUN U 2013.}

Po ulasku Hrvatske u Europsku uniju, proračun će doživjeti brojne strukturne promjene, od kojih će pojedine imati jednokratan učinak vidljiv samo u 20I3., dok će neke trajno utjecati na proračunske novčane tokove. U ovom dijelu rada cilj je procijeniti stvarne učinke pristupanja na hrvatski proračun u 2013. godini, koja je ujedno i posljednja godina aktualne financijske perspektive 2007-2013., a o potencijalnim učincima u razdoblju od 20I4. do 2020. bit će više riječi u sljedećem dijelu rada.

Prije pristupanja EU zemlje pristupnice dužne su uskladiti porezni i carinski sustav sa standardima EU. Hrvatska je do sada to većim dijelom i učinila. Prema Izvješću o napretku iz 20II. godine (Europska komisija, 20IIc), hrvatski zakonodavni okvir koji regulira indirektno oporezivanje gotovo je u potpunosti usklađen s pravnom stečevinom EU. Manja usklađivanja se očekuju tek u sustavu oporezivanja dodane vrijednosti po pitanju obuhvata sniženih stopa i izuzeća, slobodnih zona i posebnih programa.

U Hrvatskoj se još uvijek primjenjuje nulta stopa PDV-a na određenu grupu proizvoda, dok EU ne dopušta nultu stopu nego maksimum dvije snižene stope koje ne smiju biti niže od $5 \%$ (Direktiva II2/2006/EC Europske unije, 2006). Sopek (2012) procjenjuje da će prilikom usklađivanja sniženih stopa sa smjernicama EU, uz pretpostavku zadržavanja ostalih stopa nepromijenjenima, prihodi države porasti na godišnjoj razini otprilike za iznos ekvivalentan o,4\% BDP-a u slučaju primjene najniže propisane stope od $5 \%$ na isporuke koje se trenutno oporezuju nultom stopom, odnosno o,8\% u slučaju primjene stope od Io\%.

Zbog usklađivanja sa smjernicama EU u Hrvatskoj se može očekivati dodatno usklađivanje sustava trošarina povezano s trošarinama na ugljen, plin i struju te minimalnim stopama trošarina (Europska 
komisija, 20IIc). Prema Izvješću o ispunjavanju obveza iz poglavlja I6. Porezi za razdoblje do ožujka 20Io. ističe se da je u cilju usklađivanja trošarinskog zakonodavstva Hrvatske s pravnom stečevinom EU donesen novi Zakon o trošarinama (NN 83/og) koji je stupio na snagu I. siječnja 20Io. Navedeni zakon usklađen je s Direktivom 92/12/EEC, te uključuje odredbe o naplati trošarina na robu koja sukladno pravnoj stečevini EU podliježe trošarinama - energenti i električna energija, duhanski proizvodi te alkohol i alkoholna pića (Vlada RH, 2OIoa). Naknadno, Uredbom o visini trošarine na duhanske proizvode (NN IO2/IO) predloženo je povećanje proporcionalne trošarine s 30 na 33\% od maloprodajne cijene. Ovim se povećanjem udio ukupne trošarine (specifične i proporcionalne) povećao i približio minimalnom iznosu od 57\% kojeg određuje europsko zakonodavstvo (Kuliš, 20Io). U pogledu obveze dostizanja minimuma udjela ukupne trošarine od 6o\% prosječne ponderirane maloprodajne cijene cigareta puštenih u potrošnju i minimalnog iznosa od go eura na I.ooo komada cigareta do I. siječnja 20I4., Hrvatska je tražila prijelazno razdoblje do kraja 20I7. za dostizanje spomenutih zahtjeva, kao što je to predviđeno za pojedine države članice EU. Nadalje, Direktivom 2008/II8/EC od I6. prosinca 2008., a koja je stupila na snagu I. travnja 20IO., uvodi se zakonodavni okvir za elektronsko plaćanje i kontrolu kretanja trošarinske robe. Slijedom tehničkih konzultacija s predstavnicima službi Europske komisije, Hrvatska bi najkasnije do dana pristupanja u članstvo EU, trebala uskladiti svoje trošarinsko zakonodavstvo s Direktivom 2008/II8/EC, kao što bi u istom potezu trebala izvršiti i izmjene i dopune Zakona o trošarinama u dijelu koji se tiče nastanka obveze obračuna trošarine na prirodni plin i električnu struju (Vlada RH, 2OIob). Budući da ne postoji javno objavljena analiza mogućih financijskih implikacija navedenih usklađivanja, a imajući u vidu da su glavne kategorije trošarina usklađene sa smjernicama $\mathrm{EU}^{7}$, za analizu u nastavku pretpostavit ćemo da će ukupan neto učinak biti zanemariv. Ipak, predlaže se iniciranje detaljne analize odstupanja hrvatskog i europskog sustava trošarina te procjena neto učinka usklađivanja. Osim potencijalnih troškova ili koristi za proračun opće države, ta bi analiza svakako trebala obuhvatiti i potencijalne učinke na ukupne troškove poreznih vlasti, kao i ostale troškove izazvane ekonomskim poremećajima prouzročenim samom prirodom poreza poput promjena u potražnji za tim proizvodima te posljedično promjene cijena i ponude tih proizvoda.

Stupanj usklađenosti hrvatskog carinskog sustava s europskim je iznimno visok te se očekuju tek manje promjene u carinskom zakonodavstvu. Hrvatske carinske tarife za 20II. usklađene su s Kombiniranom nomenklaturom EU za 20II. Manja odstupanja prisutna su još samo u sustavu dodijeljenih kvota, autorizaciji ulaznog/izlaznog procesiranja, krajnjoj namjeni i aranžmanima unutrašnjeg tranzita (Europska komisija, 20IIc). Međutim, po pristupanju u EU Hrvatska će izgubiti znatan dio prihoda od carina koji ostvaruje sa zemljama EU, zbog ulaska na zajedničko unutarnje tržište EU, odnosno pristupanja carinskoj uniji koja podrazumijeva slobodno kretanje roba i usluga ukidanjem fizičkih i tehničkih granica između Hrvatske i zemalja EU. Drugim riječima, po ulasku u EU carinama će biti podložne jedino robe uvezene iz zemalja izvan granica EU. Prema podacima Državnog zavoda za statistiku (2OI2), u 20Io. Hrvatska je uvezla roba i usluga u vrijednosti IIo mlrd. HRK, od čega 66 mlrd.

\footnotetext{
${ }^{7}$ Ovdje se prvenstveno misli na trošarine na naftne derivate ( $53 \%$ ukupnih prihoda od trošarina u 2oIr.), duhanske prerađevine (31\%) te alkohol i alkoholna pića (7,4\% ukupnih prihoda od trošarina u 20II.) (Vremenske serije podataka Ministarstva financija $\mathrm{RH}, 2 \mathrm{OI2}$ ).
} 
HRK (60\%) iz zemalja EU. U 2OII. uvoz se povećao na I2I mlrd. HRK, od čega je 75 mlrd. HRK (62\%) ostvareno sa zemljama EU (DZS, 2OI2). Uz pretpostavku zadržavanja sličnog omjera uvoza iz zemalja EU i u 20I3. (60\%), u drugoj polovici godine će svega 40-ak posto uvoza biti podložno carinama, od čega će se $75 \%$ prihoda transferirati u proračun EU kao tradicionalni vlastiti prihodi proračuna EU. Zbog povećanog uvoza u 20II., povećao se i omjer prihoda od carina s o,49\% BDP-a u 20IO. na o,52\% BDP-a u 20II. (Ministarstvo financija baza podataka). Uz pretpostavku prosječnog omjera prihoda od carina $u$ BDP-u od o,5\%, u 20I3. može se očekivati smanjenje prihoda od carina u ukupnom iznosu od oko o,225\% BDP-a, što je dobiveno donjim izračunom:

$$
\frac{0,5 \%}{2} \cdot 60 \%+\frac{0,5 \%}{2} \cdot(1-60 \%) \cdot 75 \%=0,225 \% B D P
$$

Obzirom da će navedeni uvjeti vrijediti samo u drugoj polovici 20I3. kad Hrvatska postane formalna članica EU, oba se sumanda gornjeg izraza moraju dijeliti s 2 da bi se izračun sveo na polugodišnju razinu. Prvi sumand u izračunu iznosi ukupno o,I5\% BDP-a, a prikazuje gubitak proračuna zbog ukidanja carina na unutrašnjem tržištu, pri čemu će se po ulasku u EU 60\% polugodišnjeg prihoda od carina automatski izgubiti zbog robne razmjene sa zemljama EU. Drugi sumand u ukupnom iznosu 0,075\% BDP-a prikazuje tzv. tradicionalne vlastite prihode proračuna EU, odnosno ostatak od 40\% polugodišnjeg prihoda od carina raspodijelit će se na proračun EU i hrvatski proračun u omjeru 3:I. Prema definiranim ključevima, 75\% (o,075\% BDP-a) polugodišnjeg uvoza podložnog carinama pripast će proračunu EU, a ostatak od 25\% (o,O25\% BDP-a) ostaje u hrvatskom proračunu.

Važno je također naglasiti da će ulaskom Hrvatske u EU prestati važiti svi sporazumi o slobodnoj trgovini s trećim zemljama koje je Hrvatska samostalno potpisala, uključujući i Srednjoeuropski ugovor o slobodnoj trgovini (CEFTA). To će gotovo sigurno imati određene reperkusije na uvjete robne razmjene, a prvenstveno u regionalnim okvirima, s nepovoljnim učinkom na trgovinsku bilancu Hrvatske. Istodobno, po pristupanju EU Hrvatska će biti dužna primjenjivati sporazume koje su sklopile sadašnje zemlje članice EU s trećim zemljama ili s međunarodnim organizacijama.

Po ulasku u EU iz hrvatskog proračuna će se u 2013. odlijevati sredstva u proračun EU prema primijenjenoj stopi od o,3\% na osnovicu PDV-a (VAT base) ili na 50\% hrvatskog BND-a. Prema podacima Europske komisije (2007a), osnovica hrvatskog PDV-a procijenjena je na 57\% BND-a, što znači da ćemo za izračun prihoda od PDV-a koristiti stopu od o,3\% na 50\% BND-a. Prema projekcijama Eurostata, omjer BDP-a i BND-a bi u 20I3. trebao iznositi oko I,O5 (Eurostat baza podataka). Prema tome, rashodi Hrvatske za EU proračun po toj osnovi iznosili bi oko o,o8\% BDP-a u 2013., što je dobiveno donjim izračunom:

$$
\frac{0,3 \cdot 50 \% \cdot 1,05}{2}=0,08 \% B D P
$$

Prva dva člana umnoška u brojniku predstavljaju primjenu stope od o,3\% na 50\% BND-a. Treći član umnoška u brojniku predstavlja omjer BDP-a i BND-a, čime se dobiva godišnji iznos rashoda hrvatskog proračuna temeljem PDV-a u BDP-u. Budući da će Hrvatska biti članica EU tek od druge polovice 2013., taj se iznos mora prepoloviti kako bi dobili polugodišnju brojku. 
Ukupni godišnji prihodi proračuna EU na temelju BND-a iznosili su oko o,75\% BND-a svih zemalja članica EU u 20IO. (Europska komisija, 2OIIa). Za procjenu rashoda iz hrvatskog proračuna po toj osnovi u 20I3. godini pretpostavit ćemo zadržavanje godišnjeg udjela na razini cijelog EU proračuna od o,75\% BND-a. Ukupni iznos hrvatskih rashoda temeljem BND-a u 20I3. dobiven je donjim izračunom, a iznosi o,36\% BDP-a.

$$
\frac{0,75 \% \cdot\left(B N D_{E U-27}+\frac{1}{2} B N D_{H R}\right) \cdot \frac{\frac{1}{2} B N D_{H R}}{B N D_{E U-27}+\frac{1}{2} B N D_{H R}}}{B D P_{H R}}=0,36 \% B D P
$$

Svi podaci o projekcijama BND-a i BDP-a u 2013. korišteni u izračunu dobiveni su iz Eurostat baze podataka. Ukupni prihodi proračuna EU na temelju BND-a u 20I3. podrazumijevat će 0,75\% ukupnog BND-a svih zemalja članica EU-27 te polovicu hrvatskog BND-a (budući da će Hrvatska biti članica samo drugu polovicu 2013.). Apsolutni iznos ukupno hrvatskih rashoda temeljem BND-a u 2013. dobiven je umnoškom ukupnih prihoda proračuna EU na temelju BND-a (prva dva člana umnoška u brojniku) i udjelom hrvatskog BND-a u ukupnoj BND bazi. Za konačnu brojku potrebno je još apsolutni iznos podijeliti projekcijom BDP-a za 2013. godinu.

Prosječan godišnji udio rashoda novih zemalja članica za korekciju za Veliku Britaniju u razdoblju od 2005. do 20IO. iznosio je 0,068\% BDP-a (Europska komisija, 20IIb). Isti udio pretpostavit ćemo i u projekciji za 20I3., što bi značilo da će hrvatski doprinos na polugodišnjoj osnovi za tu stavku iznositi oko o,o34\% BDP-a.

Po ulasku u EU Hrvatska će morati izdvajati i određeni iznos za doprinos kapitalu i rezervama Europske investicijske banke (EIB). Cuculić, Faulend i Šošić (2004) procjenjuju taj iznos na o,o3\% BDP-a, što se također slaže s uplatama u prvoj godini članstva za gotovo sve zemlje koje su postale članice EU I. svibnja 2004. (Money-Go-Round.eu baza podataka) ${ }^{8}$.

Međutim, osim navedenih kategorija rashoda za proračun EU, hrvatski će proračun imati i koristi od članstva u EU koje će se manifestirati u obliku raznih transfera iz proračuna EU. U svibnju 2012. Europska komisija objavila je prijedlog proračuna EU za 20I3. (Europska komisija, 20I2) koji uključuje i cijeli financijski paket Hrvatskoj za polugodišnje razdoblje članstva. Glavne kategorije rashoda iz EU proračuna, odnosno prihoda hrvatskog proračuna, prikazane su u tablici 2.

Prema podacima iz tablice 2, Hrvatska bi u 2013. od EU trebala primiti financijska sredstva u ukupnom iznosu 396 mil. EUR ili ekvivalentno o,83\% BDP-a, od čega najveći udio od I67 mil. EUR (o,35\% BDP-a) otpada na kategoriju održivog razvoja koja uključuje podkategorije konkurentnosti za rast i zapošljavanje i kohezije za rast i zapošljavanje. Sredstva koja ovise o projektima iznose oko 159 mil. EUR (o,33\% BDP-a), a uključuju sredstva iz Strukturnih fondova u iznosu 90 mil EUR (o,I9\% BDP-a), sredstva iz Kohezijskog fonda u iznosu 60 mil. EUR (o,I3\% BDP-a) te rashode vezane za tržište koji iznose oko 9 mil. EUR (o,O2\% BDP-a). Za razliku od rashoda prema gotovinskom načelu koji obuhvaćaju očekivana

\footnotetext{
${ }^{8}$ Od svih promatranih zemalja (NMS-8) jedino je Poljska uplatila o,o4\% BDP-a za EIB u 2004., a sve ostale zemlje su uplatile o,o3\% BDP-a.
} 
financijska sredstava koja će biti isplaćena Hrvatskoj u 20I3., rashodi prema obračunskom načelu obuhvaćaju ukupan iznos aktivnosti koje bi očekivano trebale biti izvedene, odnosno fakturirane tijekom 20I3. Taj bi iznos trebao iznositi 687,5 mil. EUR ili I,44\% BDP-a, što je oko $73 \%$ više od očekivanih financijskih sredstava za isplatu. Kod kategorije 4. EU kao globalni igrač ne postoje rashodi prema obračunskom načelu, dok prema gotovinskom načelu ti rashodi postoje i iznose 77,6 mil. EUR. Radi se o tome da se ulaskom u EU Hrvatskoj prestaju alocirati sredstva namijenjena vanjskoj politici, odnosno pomoći u pretpristupanju, već će financiranje Hrvatske postati dijelom internih politika EU. Stoga, u 20I3. neće biti novih ugovorenih isplata iz pretpristupnih fondova, ali bi trebalo biti isplata za projekte ugovorene u ranijim razdobljima, što se vidi u gotovinskom obračunu.

\section{TABLICA 2.}

Financijski paket EU namijenjen Hrvatskoj u 2OI3. (mil. EUR i \% BDP-a)

\begin{tabular}{|c|c|c|c|c|}
\hline & \multicolumn{2}{|c|}{$\begin{array}{c}\text { Rashodi prema } \\
\text { obračunskom načelu }\end{array}$} & \multicolumn{2}{|c|}{$\begin{array}{l}\text { Rashodi prema } \\
\text { gotovinskom načelu }\end{array}$} \\
\hline & mil. EÜR & $\%$ BDP & mil. EUR & $\%$ BDP \\
\hline I. Održivi razvoj $(\mathrm{Ia}+\mathrm{Ib})$ & 496,8 & $\mathrm{I}, \mathrm{O} 4$ & 167,4 & 0,35 \\
\hline Ia Konkurentnost za rast i zapošljavanje & 47,4 & O,IO & 17,6 & 0,04 \\
\hline Ib Kohezija za rast i zapošljavanje & 449,4 & 0,94 & 149,8 & $0,3 \mathrm{I}$ \\
\hline od čega Strukturni fondovi & 299,6 & 0,63 & 89,9 & 0,19 \\
\hline od čega Kohezijski fond & 149,8 & $0,3 \mathrm{I}$ & 59,9 & 0,13 \\
\hline 2. Očuvanje i upravljanje prirodnim resursima & 20,4 & $\mathrm{O}, \mathrm{O} 4$ & $\mathrm{I} 2, \mathrm{I}$ & 0,03 \\
\hline $\begin{array}{l}\text { od čega rashodi vezani za tržište i direktna } \\
\text { plaćanja }\end{array}$ & 9,0 & 0,02 & 9,0 & $\mathrm{O}, \mathrm{O} 2$ \\
\hline 3. Građanstvo, sloboda, sigurnost i pravda & 73,3 & 0,15 & 42,2 & 0,09 \\
\hline 4. EU kao globalni igrač & 0,0 & $\mathrm{O}, \mathrm{OO}$ & 77,6 & 0,16 \\
\hline 5. Administracija & 22,0 & 0,05 & 22,0 & 0,05 \\
\hline 6. Kompenzacije (sredstva novčanih tokova) & 75,0 & 0,16 & 75,0 & 0,16 \\
\hline Ukupno & 687,5 & $\mathrm{I}, 44$ & 396,3 & 0,83 \\
\hline
\end{tabular}

Izvor: Europska komisija (2012); prilagodba autora.

Tablica 2. ne uključuje izravna plaćanja za koja je, prema podacima Ministarstva financija (2012), u 2013. godini predviđeno 93,2 mil. EUR. Ta će sredstva biti isplaćena u 20I4. godini za obveze plaćanja poljoprivrednicima prema hektaru obradive površine iz 2013. Prema podacima Ministarstva financija (2012), ukupna omotnica za prvih pola godine članstva prema obračunskom načelu trebala bi iznositi oko 800 mil. EUR, a osim navedenih stavki iz tablice 2. ovisnih o različitim projektima, omotnica obuhvaća još i sljedeća sredstva:

- Schengen - jačanje vanjskih granica (40 mil. EUR);

- za jačanje institucija (29 mil. EUR);

- za razminiravanje (2,4 mil. EUR);

- potpore proračunu za jačanje novčane pozicije (75 mil. EUR);

- za troškove administracije u Bruxellesu (22 mil. EUR); 
- za sudjelovanje u programima Unije - Sedmi okvirni program za istraživanja, cjeloživotno obrazovanje, Erasmus Mundus, Trans-europska mreža za energiju i transport (sve zajedno 47,4 mil. EUR).

Da bi Hrvatska doista primila iznose iz Strukturnih fondova, Kohezijskog fonda te sredstva za ruralni razvoj, primarna joj je zadaća uspostaviti adekvatne administrativne apsorpcijske kapacitete te osmisliti i pripremiti adekvatne projektne aktivnosti. Također, potrebno je osigurati sredstva za sufinanciranje projekata na državnoj i lokalnoj razini, što će svakako predstavljati dodatan teret za hrvatski proračun. Minimalno propisan udio sufinanciranja zemlje članice iznosi $25 \%$ ukupnih sredstava iz Strukturnih fondova i sredstava za ruralni razvoj te $15 \%$ sredstava iz Kohezijskog fonda. Povijesno gledano, EU je sufinancirala projekte uglavnom između 50 i 85\% (The European Bank Coordination (“Vienna”) Initiative, 2OII), dok je ostatak do punog iznosa vrijednosti projekta bila dužna sufinancirati sama zemlja članica.

Iz iznosa sredstava financiranih od strane EU prikazanih u tablici 2, vrlo lako se dobije iznos sredstava koje je dužna osigurati sama zemlja članica (u našem slučaju Hrvatska) za sufinanciranje projekata. Taj iznos ovisi o primijenjenoj stopi sufinanciranja od zemlje članice, a može se izraziti sljedećom formulom:

$$
R_{i}^{M S}=R_{i}^{E U} \cdot \frac{r_{i}}{1-r_{i}}
$$

gdje je $R_{i}^{E U}$ iznos sredstava za financiranje projekata iz proračuna EU, a $r_{i}$ prosječna primijenjena stopa sufinanciranja od same zemlje članice. Indeks $i$ označava kategoriju, odnosno Strukturni fondovi, Kohezijski fond ili sredstva za ruralni razvoj.

Iz izračuna dobivenog primjenom formule (4) možemo zaključiti da će Hrvatska morati osigurati oko 0,09\% BDP-a za sufinanciranje projekata pod pretpostavkom minimalnog udjela sufinanciranja ( $25 \%$ ukupnih sredstava iz Strukturnih fondova i sredstava za ruralni razvoj te I5\% sredstava iz Kohezijskog fonda), odnosno o,I5\% BDP-a ukoliko primijenimo udio sufinanciranja za Io postotnih bodova veći od minimalno propisanog (35\% ukupnih sredstava iz Strukturnih fondova i sredstava za ruralni razvoj te $25 \%$ sredstava iz Kohezijskog fonda).

Izračunom objašnjenim u prethodnom dijelu teksta i prikazanim u tablici 3. pokazuje se da bi Hrvatska u 20I3. trebala financijski profitirati od članstva u EU. Neto pozicija Hrvatske u proračunu EU u 2013. pokazuje da bi Hrvatska, baš kao i većina novih zemalja članica, trebala biti neto primateljica sredstava u iznosu od oko o,28\% BDP-a, odnosno preračunato u nominalni iznos oko I36 mil. EUR ${ }^{9}$. Također, ukupna neto financijska pozicija Hrvatske zbog pristupanja EU u 20I3. trebala bi iznositi oko 0,I5\% BDP-a, odnosno oko 72 mil. EUR.

Važno je naglasiti da se brojke iz tablice 3. mogu korektno interpretirati isključivo uz pretpostavku da se sva sredstva iz proračuna EU prikazana u tablici 2. slijevaju direktno u proračun opće države, odnosno da sva sredstva iz EU fondova koristi isključivo javni sektor. Implicitno sadržana pretpostavka

\footnotetext{
${ }^{9}$ Nominalni iznos dobiven je množenjem procijenjenog učinka (\% BDP) s projekcijom BDP-a za 20I3. (Eurostat baza podataka).
} 
u izračunima jest i ta da sva sredstva doista stvaraju učinak supstitucije, tj. da zamjenjuju nacionalno financiranje po određenim područjima. U suprotnome bi razina nacionalnog financiranja ostala jednaka, dok bi dio sredstava iz proračuna EU bio dodatan izvor sredstava za projekte i potpore, ali i dodatan pritisak na proračun.

\section{TABLICA 3.}

Neto pozicija Hrvatske u EU proračunu i financijski troškovi/koristi pristupanja u 2013. (\% BDP-a)

\begin{tabular}{|c|c|c|}
\hline Kategorija prihoda/rashoda & $\%$ BDP & Mil. EUR \\
\hline I. Isplate iz EU proračuna & 0,83 & 396,30 \\
\hline Strukturni fondovi & O,I9 & 89,90 \\
\hline Kohezijski fond & O,I3 & 59,90 \\
\hline Rashodi EU proračuna vezani za tržište i direktna plaćanja & 0,02 & 9,00 \\
\hline Ostali rashodi EU & 0,50 & 237,50 \\
\hline 2. Uplate u EU proračun & 0,55 & 260,33 \\
\hline Tradicionalni vlastita sredstva & 0,08 & $35,8 \mathrm{I}$ \\
\hline Rashodi temeljem PDV-a & 0,08 & 37,56 \\
\hline Rashodi temeljem BND-a & 0,36 & I70,66 \\
\hline Korekcija za Veliku Britaniju & 0,03 & 16,30 \\
\hline 3. Ostali troškovi/koristi $(-/+)$ & $-0,13$ & $-63,67$ \\
\hline Doprinos za EIB $(-)$ & $\mathrm{O}, \mathrm{O} 3$ & 14,32 \\
\hline Primjena sporazuma o slobodnoj trgovini (-) & $\mathrm{O}, \mathrm{I5}$ & $7 \mathrm{I}, 6 \mathrm{I}$ \\
\hline Sufinanciranje projekata - prosječne stope $(-)$ & O,I5 & 73,22 \\
\hline Sufinanciranje projekata - minimalne stope & 0,09 & 43,54 \\
\hline Ukidanje nulte stope PDV-a (+) & 0,20 & 95,49 \\
\hline Trošak institucija i reformi (-) & $?$ & ? \\
\hline Neto pozicija Hrvatske u EU proračunu (I-2) & 0,28 & 135,97 \\
\hline Financijski troškovi/koristi pristupanja (I-2-3) & 0,15 & 72,29 \\
\hline
\end{tabular}

Izvor: izračun autora.

Nadalje, jedan dio troškova je gotovo nemoguće procijeniti budući da ne postoje javno dostupni podaci o troškovima izgradnje i održavanja institucija, kao ni podaci o troškovima provođenja reformi pa je taj dio izostavljen iz analize. Međutim, trošak institucija uključenih u provedbu programa EU već je ionako uključen u proračun budući da je institucionalni okvir za korištenje europskih fondova uglavnom nastavak strukture koja je već uključena u provedbu pretpristupnog programa (Ministarstvo financija, 20Io). Stoga ovi učinci niti ne bi trebali imati utjecaja na ovu analizu.

\section{Proračunska perspektiva Hrvatske u razdoblju dO 2020.}

Nakon ulaska u EU sredstva iz EU proračuna bit će namijenjena jačanju prometne infrastrukture, a osobito željezničkog prometa, vodna gospodarstva, projekte centara za upravljanje otpadom, energetiku, povezivanje znanosti i gospodarstva te jačanje poslovne infrastrukture. Posebna pažnja posvećuje se i tržištu rada, uključivanju teže zapošljivih skupina stanovništva u rad, provedbi programa cjeloživotnog učenja i prekvalifikacija kako bi se izgradila što fleksibilnija i konkurentnija radna snaga (Ministarstvo financija, 2012). 
Stvarne učinke nakon 20I3. nije moguće adekvatno procijeniti, budući da je još uvijek velik dio prihoda i rashoda proračuna EU pod posebnim povećalom te se razmatra optimalan model financiranja i implementacije. Ipak, u svrhu procjene budućih očekivanih kretanja neto novčanih tokova iz EU proračuna, možemo se poslužiti iskustvima novih zemalja članica. U ovom kontekstu nove zemlje članice obuhvaćaju 8 zemalja koje su postale punopravne članice EU od I. svibnja 2004., a to su Češka, Estonija, Latvija, Litva, Mađarska, Poljska, Slovačka i Slovenija. Te su zemlje posebno zanimljive jer su, baš kao što bi trebala i Hrvatska, postale punopravne članice EU tijekom godine, a s Hrvatskom ih veže i slična geografska, politička i socijalna pozadina.

Sredstva iz Strukturnih fondova i Kohezijskog fonda dostupna su regijama, odnosno zemljama koje imaju BDP po stanovniku niži od određenog postotka EU. Za Strukturne fondove i Kohezijski fond taj postotak iznosi 75\%, a za poseban aranžman tranzicije u sklopu kohezijske politike sredstva su dostupna zemljama s BDP-om po stanovniku između 75 i 90\% europskog prosjeka. Hrvatska je prema podacima Eurostata u 20IO. imala BDP po stanovniku jednak 6I\% prosjeka EU, što znači da će u narednom razdoblju biti kandidat za primanje sredstava iz Strukturnih fondova i Kohezijskog fonda. Na grafikonu 5. je prikazano kretanje BDP-a po stanovniku novih zemalja članica i Hrvatske u razdoblju 1995-20IO.

\section{GRAFIKON 5.}

BDP po stanovniku mjeren standardom kupovne moći izražen kao prosjek EU-27 u razdoblju 1995-20Io.

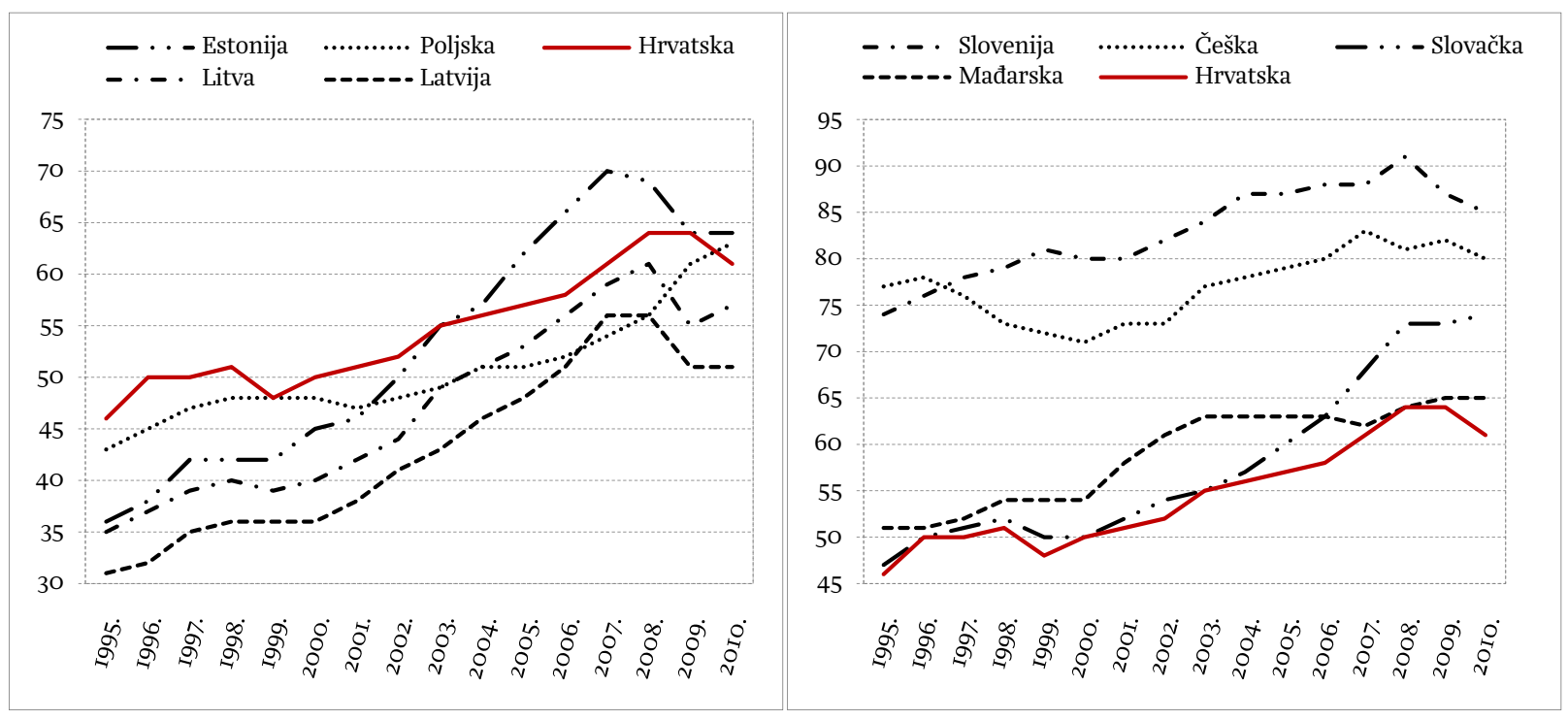

Izvor: izračun autora.

U čitavom razdoblju od 1995-20IO. sve su nove zemlje članice, baš kao i Hrvatska, bile ispod prosjeka svih 27 zemalja članica EU, ali su bilježile rast BDP-a po stanovniku u odnosu na prosjek EU-27º Općenito se može zaključiti da su zemlje s višim početnim BDP-om po stanovniku zabilježile i sporiji rast i obratno. Sporiji trend rasta od Hrvatske u promatranom razdoblju zabilježile su jedino Slovenija, koja je imala značajno viši BDP po stanovniku u 1995. (74\% prosjeka EU-27) u odnosu na Hrvatsku (46\%

\footnotetext{
${ }^{10}$ Prosjek EU-27 označen je sa Ioo, a izračunat je retroaktivno za razdoblje 1995-2004. na način da uključuje prosjek svih 27 trenutnih zemalja članica, iako u tom razdoblju te zemlje nisu bile formalne članice EU.
} 
prosjeka EU-27), te Poljska i Mađarska koje su 1995. imale relativno sličan BDP po stanovniku kao i Hrvatska (Mađarska 5I\%, a Poljska 43\% prosjeka EU-27) ${ }^{\text {II }}$. Stoga možemo pretpostaviti da je pretpristupna faza zajedno s članstvom u EU ipak imala određeni utjecaj na poticanje rasta gospodarske aktivnosti. Uz optimističnu pretpostavku srednjoročnog trenda rasta kao u razdoblju od 2000. do 20IO. (rast s 50 na 6I\% prosjeka EU-27, odnosno 22\%), Hrvatska bi u 202O. mogla dosegnuti prag od 74,4\% BDP-a EU-27, što bi značilo da bi se približila pragu tranzicijskih zemalja. Ipak, s obzirom na trenutne gospodarske okolnosti, gotovo je nevjerojatno da bi u narednom razdoblju do 2020 . Hrvatska uspjela zabilježiti rast realne gospodarske aktivnosti kao u razdoblju prije krize. Stoga realniji scenarij predviđa puno slabiji rast BDP-a po stanovniku u odnosu na prosjek EU na tek 63\% u 2020. ${ }^{\text {I2 }}$

\section{I. ISKUSTVA NOVIH ZEMALJA ČLANICA U PRVIM GODINAMA ČLANSTVA U EU}

U nastavku slijedi analiza proračunskih prihoda novih zemalja članica u razdoblju 2004-20Io., što će kasnije poslužiti u gruboj procjeni hrvatskog potencijala. Grafikon 6 prikazuje udio prihoda iz Strukturnih fondova u BDP-u u novim zemljama članicama.

\section{GRAFIKON 6.}

Prihodi iz Strukturnih fondova novim zemljama članicama (\% BDP-a)

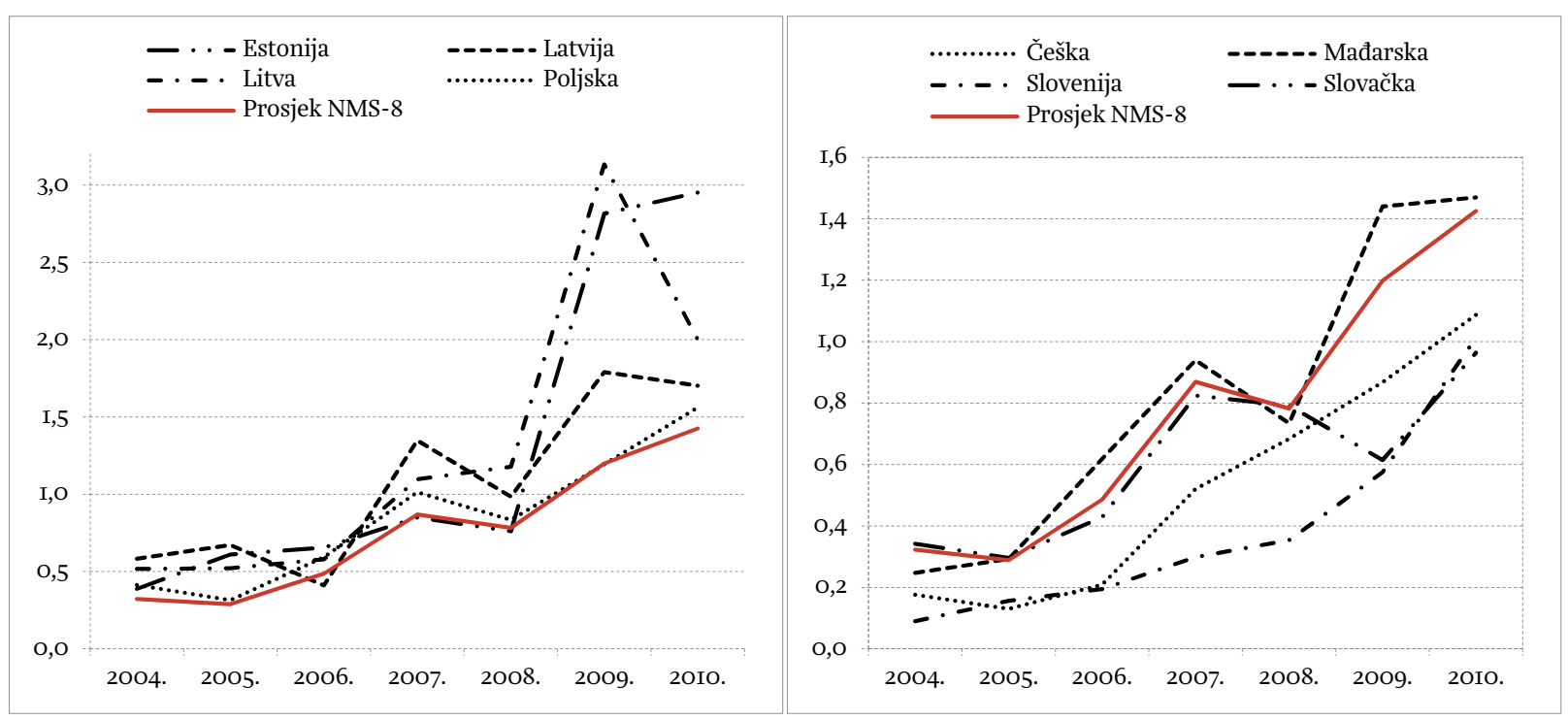

Izvor: izračun autora.

Prosjek novih zemalja članica pokazuje jasan trend rasta prihoda iz Strukturnih fondova od trenutka ulaska u EU pa do 20IO. Očekivano, u prvim godinama članstva zbog implementacije početnih projektnih aktivnosti i razvoja apsorpcijskih kapaciteta udio sredstava iznosi manje od o,5\% BDP-a. U sedmoj godini članstva prosječan udio prihoda iz Strukturnih fondova doseže gotovo I,5\% BDP-a.

\footnotetext{
II Trend rasta u ovom slučaju označava nagib (koeficijent smjera) linearnog regresijskog pravca pojedine zemlje.

${ }^{12}$ Izračunato pomoću aktualnih procjena rasta BDP-a za Hrvatsku u 2012. i 2OI3. dostupnih u priopćenju Ekonomskog instituta iz Zagreba (20I2) u kojem se predviđa realna stopa rasta hrvatskog BDP-a od -I,3\% u 20I2. i o,8\% u 20I3. Za daljnje projekcije, kao i za projekciju prosječnog realnog rasta BDP-a zemalja EU korištene su dugoročne prognoze MMF-a (2OI2a, 2OI2b). Zbog jednostavnosti izračuna BDP-a po stanovniku, pretpostavlja se da se broj stanovnika Hrvatske i EU neće bitno promijeniti.
} 
Zanimljivo je pritom uočiti Litvu u 2009. i Estoniju u 20Io. koje su uspjele povući sredstva u ukupnom iznosu od oko 3\% BDP-a.

\section{GRAFIKON 7.}

Prihodi iz Kohezijskog fonda novim zemljama članicama (\% BDP-a)

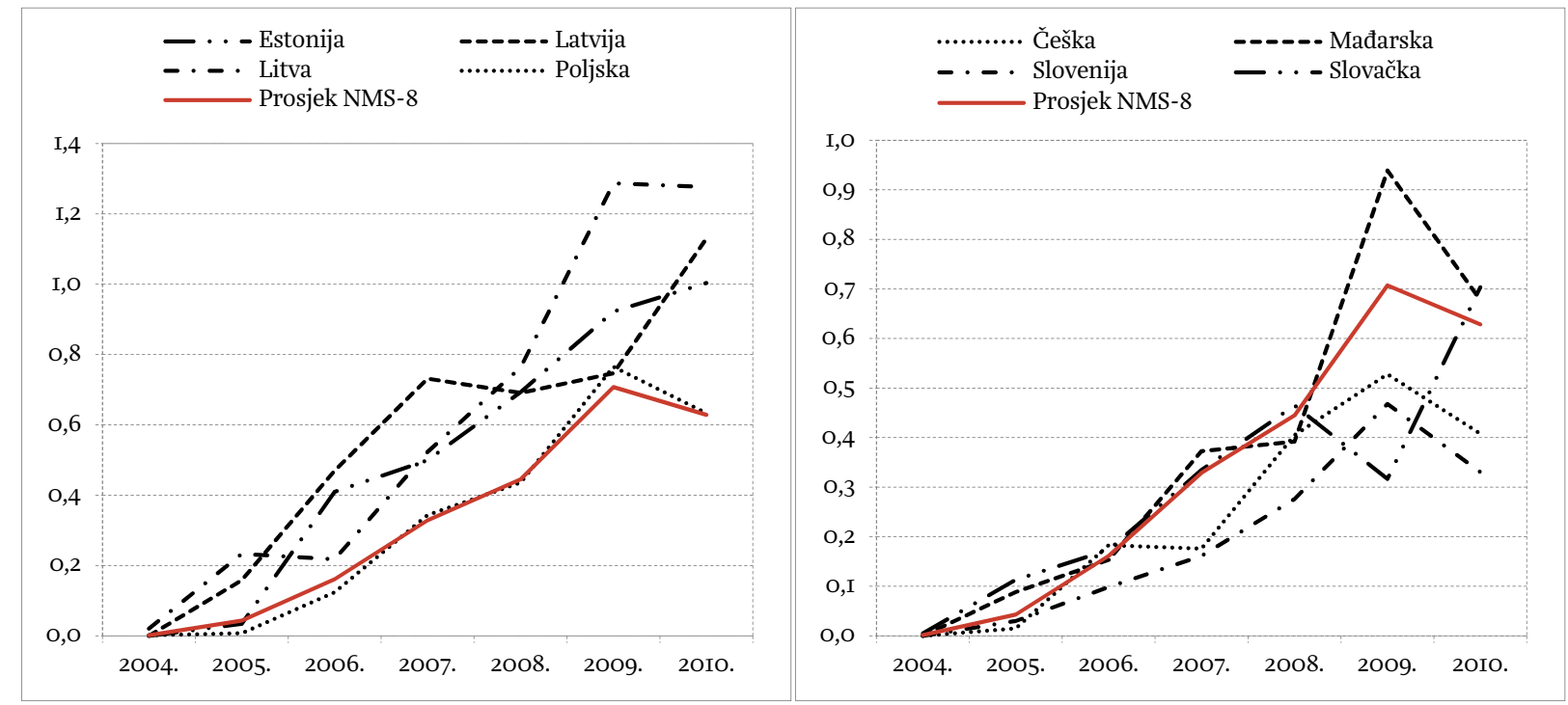

Izvor: izračun autora.

\section{GRAFIKON 8.}

Prihodi iz sredstava za ruralni razvoj novim zemljama članicama (\% BDP-a)

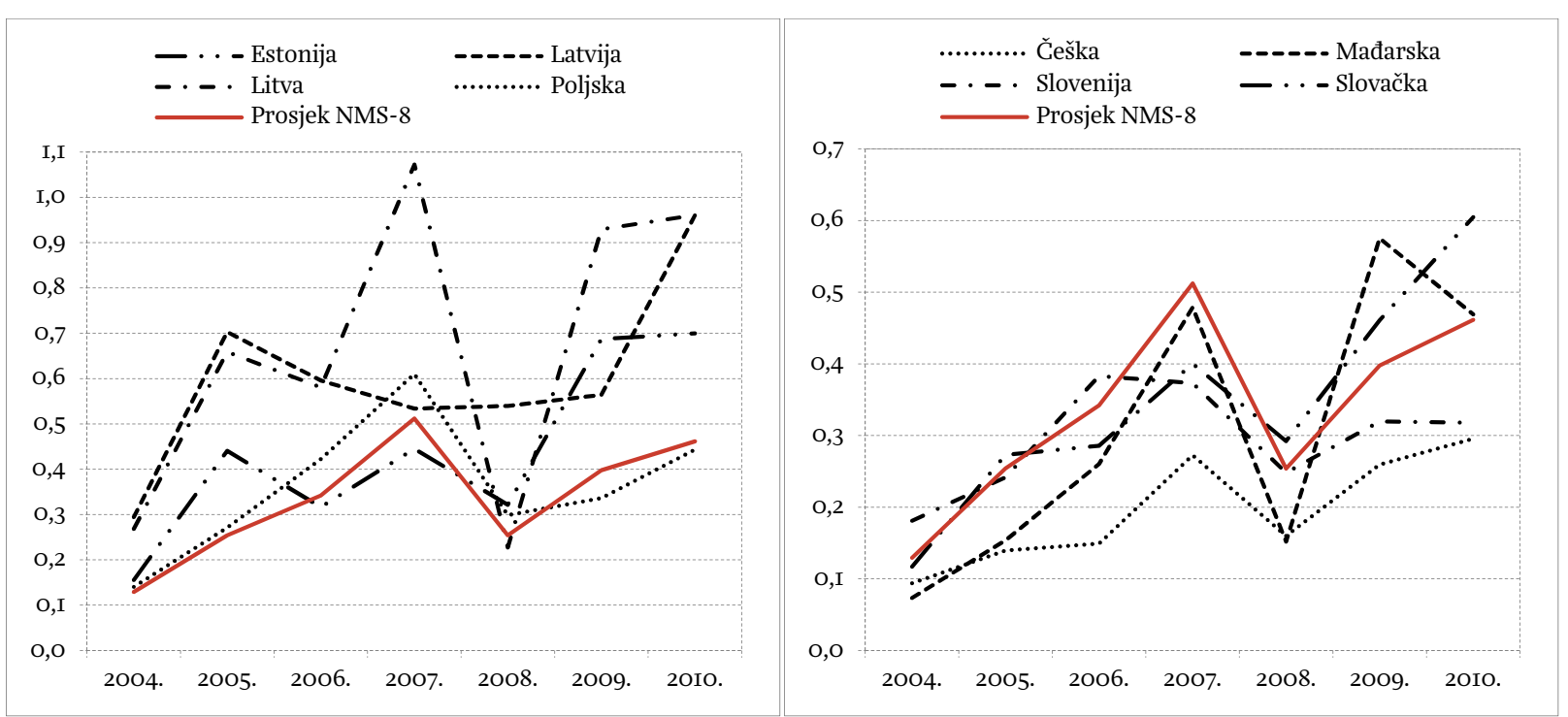

Izvor: izračun autora.

Slično kao i kod Strukturnih fondova, sve su nove zemlje članice zadovoljavale kriterij za dobivanje sredstava iz Kohezijskog fonda. Obzirom da je i Kohezijski fond projektno orijentiran, sredstva koja pojedina zemlja članica uspije povući iz proračuna EU ovise o projektima pa je i razumljivo da se iznos sredstava povećava iz godine u godinu kako rastu apsorpcijski kapaciteti. U prve dvije godine iznos isplaćenih sredstava gotovo je zanemariv, da bi nakon toga iz godine u godinu iznos rastao za prosječno 
O,I-O,2\% BDP-a. U promatranom razdoblju od 2004. do 20IO. najviše sredstava iz Kohezijskog fonda je uspjela povući Litva i to u 2009. i 20IO. u iznosu od oko I,3\% BDP-a.

Sredstva za ruralni razvoj pokazuju manje očigledan trend u promatranom razdoblju 2004-20Io. Ipak, kao i kod Strukturnih i Kohezijskog fonda najmanji isplaćeni iznos sredstava zabilježen je u prvoj godini članstva te se zatim povećavao. Najviši prosjek zabilježen je u 2007. i iznosi 0,5I\% BDP-a. U slučaju sredstava za ruralni razvoj Litva je također uspjela povući najviše sredstava, zajedno s Latvijom i to u 20Io. u iznosu od o,96\% BDP-a.

\section{GRAFIKON 9.}

Dohodovne potpore poljoprivrednicima novim zemljama članicama (\% BDP-a)

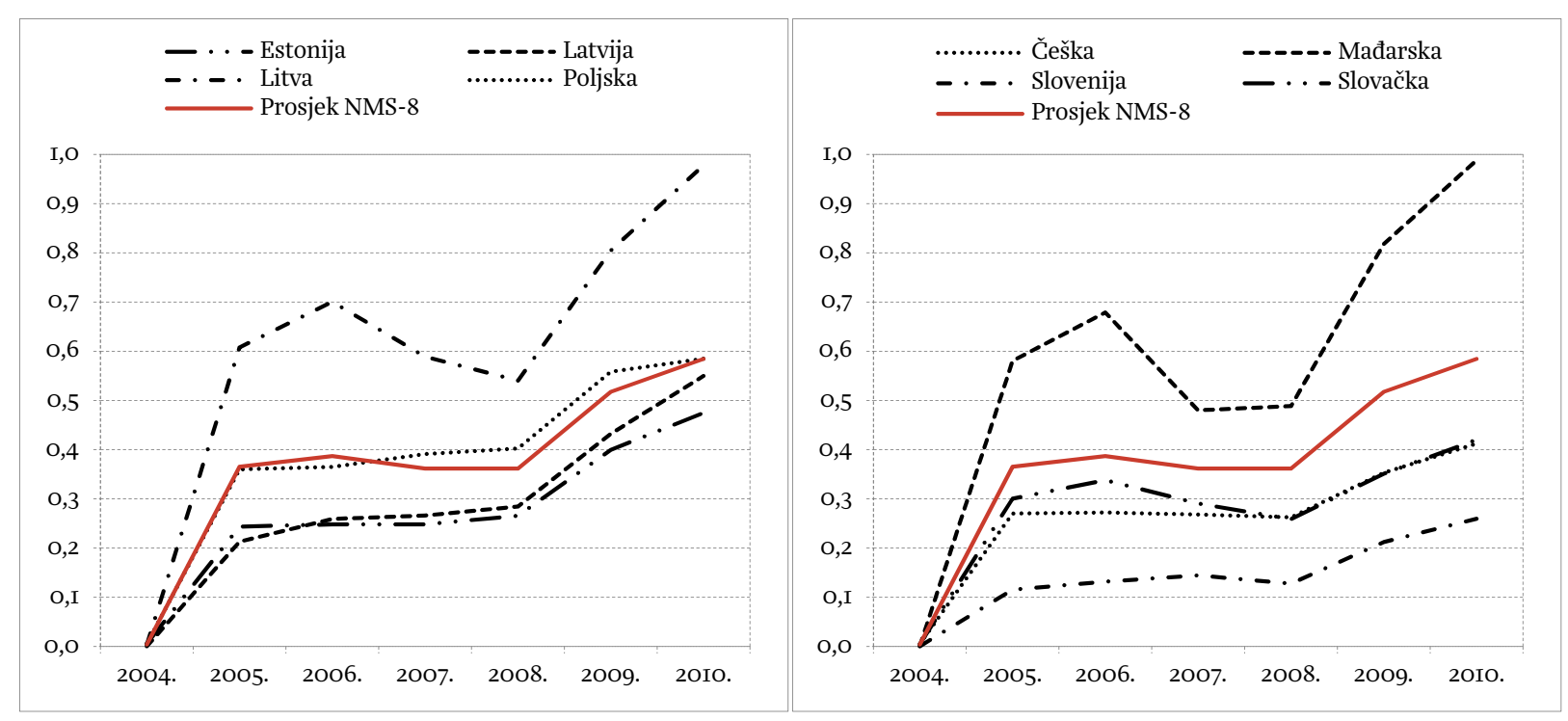

Izvor: izračun autora.

Dohodovne potpore poljoprivrednicima su isplaćene po prvi puta u 2005. Cuculić, Faulend i Šošić (2004) ističu kako isplate pojedinih potpora kasne otprilike tri mjeseca, što prenosi plaćanja u sljedeću fiskalnu godinu, a ta se pojava naziva jazom likvidnosti. U razdoblju od 2005. do 2008. prosječan iznos isplaćenih dohodovnih potpora poljoprivrednicima kretao se na otprilike sličnim razinama (prosječno 0,37\% BDP-a), da bi se u 2009. povećao na 0,52\% BDP-a i u 2010. na 0,58\% BDP-a.

Kao što je već i ranije napomenuto, kohezijska politika obuhvaća Strukturne fondove i Kohezijski fond, a politika prirodnih resursa obuhvaća sredstva iz Zajedničke poljoprivredne politike. Na grafikonu Io. prikazan je odnos isplaćenih i alociranih sredstava novih zemalja članica u razdoblju 2007-20IO. po ove dvije kategorije. 


\section{GRAFIKON IO.}

Odnos isplaćenih i alociranih sredstava (\%)

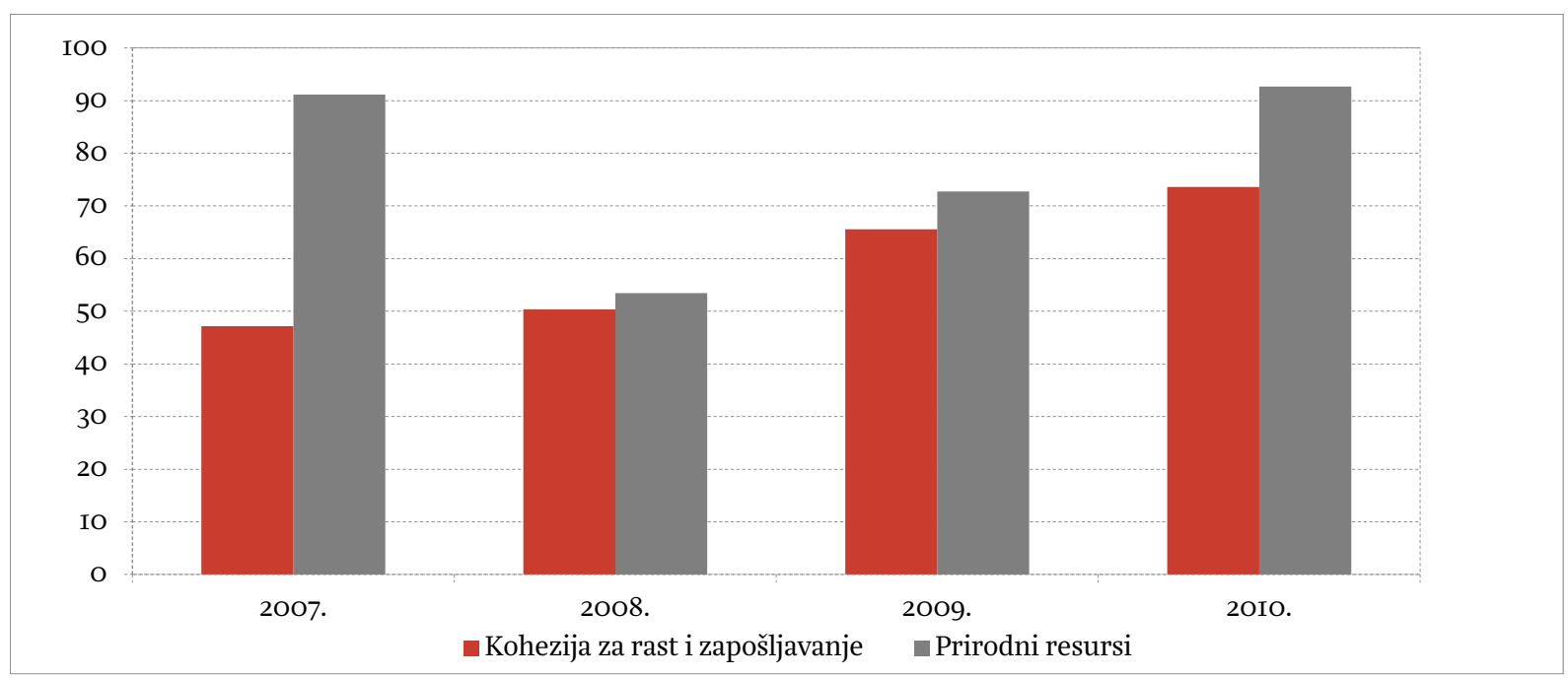

Izvor: izračun autora temeljem Europske komisije (2007b, 2007c, 20IIb).

Grafički prikaz jasno ukazuje na trend rasta udjela iskorištenih sredstava u promatranom razdoblju kod kohezijske politike koja je porasla s prosječnih 47,2\% u 2007. na 73,6\% u 2010. Među zemljama članicama vidljive su značajne razlike po pojedinim godinama što se pokazuje i standardnom devijacijom koja je u 2009. iznosila čak 3I postotni bod. Udjeli isplaćenih u odnosu na alocirana sredstva generalno su viši kod kategorije prirodnih resursa, međutim ovdje ne postoji očigledan trend rasta kao kod kohezije za rast i zapošljavanje. Važno je naglasiti da u alokacijama i isplatama postoje određeni vremenski pomaci u novčanim tokovima. Naime, alocirana sredstva podrazumijevaju sredstva prema obračunskom načelu te se odnose isključivo na sredstva dostupna za ugovaranje u tekućoj godini, dok isplaćena sredstva podrazumijevaju sredstva prema gotovinskom načelu, odnosno tiču se sredstava ugovorenih te godine, ali i ranijih godina, a koja u tekućoj godini dospijevaju na naplatu.

\section{GRAFIKON II.}

Ostali prihodi iz proračuna EU za nove zemlje članice (\% BDP-a)

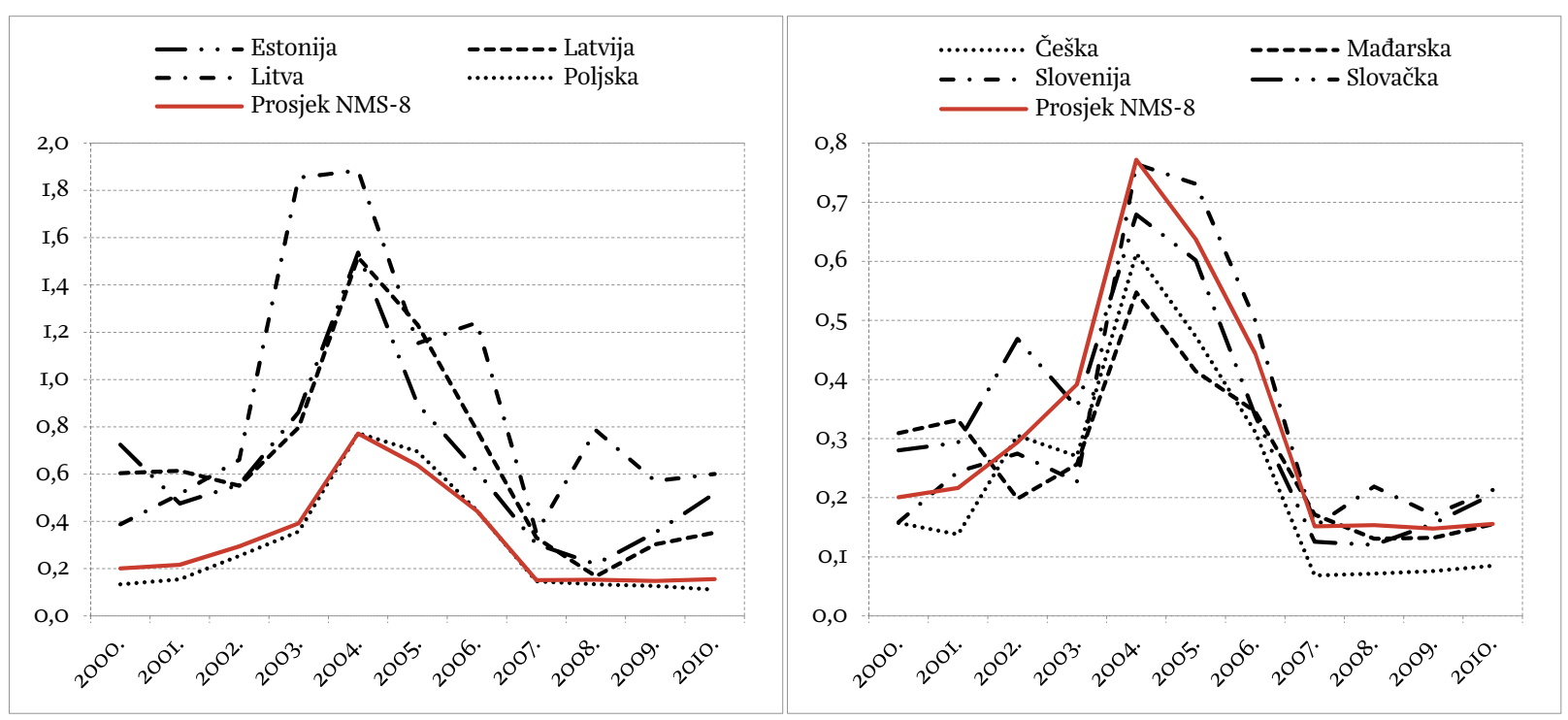

Izvor: izračun autora. 
Ostali prihodi zemalja članica obuhvaćaju i razdoblje prije formalnog članstva zato što u tu kategoriju ulaze i brojne pretpristupne pomoći, specijalni aranžmani i proračunske kompenzacije. U tim se prihodima očituje jasan trend rasta do 2004., što uključuje brojne pripreme za razvoj institucija i administracije, a u svrhu jačanja apsorpcijskih kapaciteta. Nakon 2004. prosječan udio ostalih prihoda iz EU proračuna pada, prvenstveno zbog toga što se smanjuju rezidualni novčani tokovi za ugovorene projekte pokrivene iz pretpristupnih fondova, te se u razdoblju od 2007. do 20Io. taj udio zadržava na razini od nepunih o,2\% BDP-a.

Općenito gledajući, važno je naglasiti da nemaju sve zemlje iste mogućnosti (mjereno postotkom njihovog BDP-a) glede povlačenja sredstava. Radi se o tome da neke zemlje imaju relativno veće, a neke manje alokacije sredstava u fondovima EU. Iz podataka Europske komisije (2007b, 2007c), izračunati ukupan prosjek alociranih sredstava za kategorije kohezija za rast i zapošljavanje i ruralni razvoj za nove zemlje članice u razdoblju 2007-20IO. iznosi 3,2\% BDP-a, a najviše sredstava u odnosu na BDP alocirano je Mađarskoj (4,0\%), Litvi (3,9\%) i Latviji (3,7\%). Litva općenito ima najviše udjele isplaćenih sredstava $u$ promatranom razdoblju 2004-20Io., što se najvećim dijelom može objasniti većim alociranim sredstvima. MMF (2006) ističe da je u razdoblju od 2004. do 2006. na godišnjoj razini Litvi odobreno prosječno 5,4\% BDP-a sredstava iz EU fondova, što je najviše među svim promatranim novim zemljama članicama. Sličan udio imala je i Latvija, a ostale zemlje članice imaju preko I postotni bod niže udjele u BDP-u.

\subsection{POTENGIJAL HRVATSKE U FINANGIJSKOJ PERSPEKTIVI EU OD 2OI4. DO 2020.}

Iskustva novih zemalja članica u prethodnom dijelu rada mogu nam poslužiti kao dobra podloga za procjenu hrvatskog potencijala $u$ razdoblju od 20I4. do 2020. obuhvaćenom novom financijskom perspektivom EU.

Prema podacima Ministarstva financija (2012), Hrvatskoj je od 20I4. godine pa na dalje obećan godišnji iznos sredstava od I,6 mlrd. EUR za europske fondove koji se koriste kroz kohezijsku politiku. Fond za ruralni razvoj će se u 20I3. nastaviti provoditi kroz IPARD te će iznositi 27,7 mil. EUR, a već u sljedećim godinama trebao bi biti znatno veći i iznositi oko 330 mil. EUR. U financijskoj omotnici navodi se da će sredstva fondova u 20I4. biti za 2,33 puta veća u odnosu na 20I3. godinu, te u 20I5. godini za 3 puta veća u odnosu na 20I3. godinu ${ }^{\mathrm{I} 3}$. To znači da bi u 20I4. Hrvatska na raspolaganju imala potencijal od oko I,I mlrd. EUR, a od 2015-2020. oko I,4 mlrd. EUR za korištenje iz fondova EU u kategorijama kohezijske i Zajedničke poljoprivredne politike. Međutim, ovdje je svakako važno naglasiti dvije stvari. Prvo, nova financijska perspektiva još uvijek nije usvojena tako da obećan iznos sredstava zasad još uvijek predstavlja samo moguću špekulaciju. Drugo, ukupno primljena sredstva iz ovih izvora ovisit će ponajprije o sposobnosti apsorbiranja tih sredstava, odnosno kvalitetnim projektima.

\footnotetext{
${ }^{13}$ Financijska omotnica podrazumijeva iznos sredstava koji država kandidatkinja uspije osigurati tijekom pregovaračkog procesa i koji će joj stajati na raspolaganju nakon stupanja u punopravno članstvo Europske unije. U slučaju Hrvatske dogovoreno je postupno povećanje sredstava (tzv. phase-in), pri čemu bi u prvih godinu dana (I.7.2013.-30.6.20I4.) Hrvatskoj bilo dostupno 6o\% od iznosa normalno alociranih sredstava, u narednih godinu dana 80\%, a od I.7.2015. 100\% alociranih sredstava (Ministarstvo vanjskih i europskih poslova, 20II). Dodatno, u 20I3. će ukupno alocirana sredstva biti značajno niža i zbog polugodišnjeg članstva.
} 
Slijedeći prosječne odnose isplaćenih i alociranih sredstava kao kod novih zemalja članica (grafikon Io) možemo pretpostaviti lagani i stabilan rast isplata iz fondova EU u čitavom razdoblju od 20I4-2O2O. Iz tablice 2. vidimo da je očekivani odnos isplaćenih i alociranih sredstava za kohezijsku i Zajedničku poljoprivrednu politiku u 20I3. iznosio 34,6\%. Uz pretpostavku da će Hrvatska u cijelom razdoblju bilježiti linearan rast od 34,6\% u 2013. do 76,5\% u 2020. (ponderirani prosjek kohezijske i Zajedničke poljoprivredne politike novih zemalja članica u 20Io. iz grafikona Io) te uz pretpostavku alociranih sredstava od I,I mlrd. EUR u 2OI4. i I,4 mlrd. EUR od 20I5-2020., možemo zaključiti da bi Hrvatska u novoj financijskoj perspektivi od 2014-2O2O. iz proračuna EU očekivano trebala povući sredstva vezana uz fondove u ukupnom iznosu od 5,2 mlrd. EUR. Pritom se taj iznos kontinuirano povećava iznoseći o,4 mlrd. EUR u 2OI4., o,6 mlrd. EUR u 2OI5. pa sve do I,I mlrd. EUR u 202O. Projekcije iznosa alociranih i isplaćenih sredstva iz EU fondova, kao i odnos isplaćenih i alociranih sredstava u razdoblju 20I4-2O2O. prikazani su u grafikonu I2.

\section{GRAFIKON I2.}

Alocirana i isplaćena sredstva iz EU fondova (mlrd. EUR) te odnos isplaćenih i alociranih sredstava (u \%), razdoblje 20I4-202O.

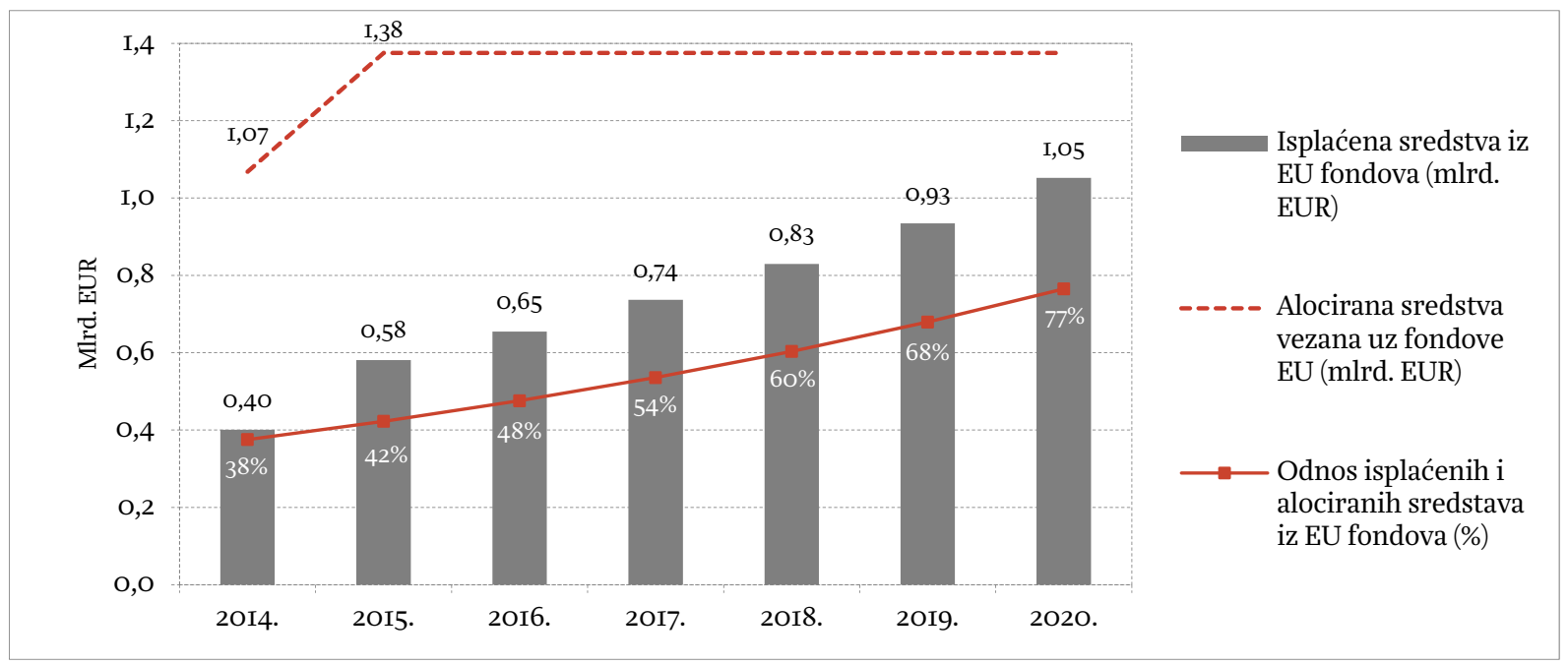

Izvor: izračun autora.

\section{TABLICA 4.}

Projekcija isplaćenih sredstava iz EU proračuna u razdoblju 2014-2020. (\% BDP-a i mlrd. EUR)

\begin{tabular}{|c|c|c|c|c|c|c|c|c|}
\hline & 2014. & 2015. & 2016. & 2017 & 2018. & 2019. & 2020. & $\begin{array}{l}\text { Ukupno } \\
\text { 2014-20. }\end{array}$ \\
\hline $\begin{array}{l}\text { I. Alocirana sredstva vezana uz } \\
\text { fondove (mlrd. EUR) }\end{array}$ & $\mathrm{I}, \mathrm{O} 7$ & $\mathrm{I}, 38$ & $\mathrm{I}, 38$ & $\mathrm{I}, 38$ & $\mathrm{I}, 38$ & 1,38 & $\mathrm{I}, 38$ & 9,32 \\
\hline $\begin{array}{l}\text { 2. Odnos isplacenih i alociranih } \\
\text { sredstava iz fondova (\%) }\end{array}$ & 37,53 & 42,26 & 47,59 & 53,59 & 60,34 & 67,94 & 76,50 & 55,69 \\
\hline $\begin{array}{l}\text { 3. Isplacena sredstva iz fondova } \\
\text { (mlrd. EUR) }\left(I^{*} 2\right)\end{array}$ & 0,40 & 0,58 & 0,65 & 0,74 & 0,83 & 0,93 & $\mathrm{I}, \mathrm{O} 5$ & 5,I9 \\
\hline $\begin{array}{l}\text { 4. Ostali prihodi iz EU } \\
\text { proračuna (mlrd. EUR) }\end{array}$ & 0,30 & $\mathrm{O}, 2 \mathrm{I}$ & O,II & $\mathrm{O}, \mathrm{I} 2$ & O,I3 & O,I4 & O,I5 & $\mathrm{I}, \mathrm{I} 5$ \\
\hline Ukupno (mlrd. EUR) (3+4) & 0,70 & 0,79 & 0,77 & 0,86 & 0,96 & $\mathrm{I}, \mathrm{O} 7$ & $\mathrm{I}, 2 \mathrm{O}$ & 6,34 \\
\hline
\end{tabular}


Prema podacima iz tablice 2., Hrvatska može računati na ostale prihode iz proračuna EU u iznosu od 237,5 mil. EUR, odnosno O,49\% BDP-a u 2013. Slijedeći jednaku dinamiku smanjivanja ostalih prihoda proračuna EU kao u grafikonu II. možemo zaključiti da bi Hrvatska u 20I4. mogla dobiti sredstva od oko o,6\% BDP-a, o,4\% BDP-a u 2015. i dalje sve do 2020. iznos od o,2\% BDP-a, odnosno ukupno oko I,I5 mlrd. EUR za razdoblje 20I4-202O. Ukupan iznos svih sredstava iz proračuna EU po godinama prikazan je u tablici 4.

Ukupan iznos svih sredstava koji bi Hrvatska mogla primiti u razdoblju od 20I4-2020. iznosi 6,34 mlrd. EUR, pri čemu se iznos lagano povećava iz godine u godinu počevši od o,7 mlrd. EUR u 20I4. na I,2 mlrd. EUR u 2020. Zanimljivo je uočiti i lagani pad ukupnih isplaćenih sredstava iz EU proračuna u 20I6. u odnosu na 20I5. Naime, ostali prihodi iz EU proračuna u prvim godinama značajno se smanjuju prvenstveno zbog smanjenih isplata ugovorenih $\mathrm{u}$ pretpristupnom razdoblju. $\mathrm{S}$ druge strane iskorištena, odnosno isplaćena sredstva iz fondova EU rastu sporijom dinamikom što je zajedno dovelo do tog pada u 20I6. Gruba procjena sredstava koja bi Hrvatska trebala primiti iz EU proračuna u financijskoj perspektivi do 2020. može poslužiti tek kao uvid u moguću perspektivu uz brojna ograničenja navedena u ranijem tekstu. Konačna realizacija ovisit će ponajprije o stvarnim alociranim sredstvima, administrativnim i financijskim apsorpcijskim kapacitetima te kvalitetnim projektnim aktivnostima.

Grafikon I3. prikazuje neto poziciju svih zemalja članica u EU proračunu u odnosu na BDP po stanovniku u 2010.

GRAFIKON I3.

Dijagram raspršenja operativnog salda EU proračuna i BDP-a po stanovniku (u tekućim cijenama) u 20Iо. po svim zemljama članicama

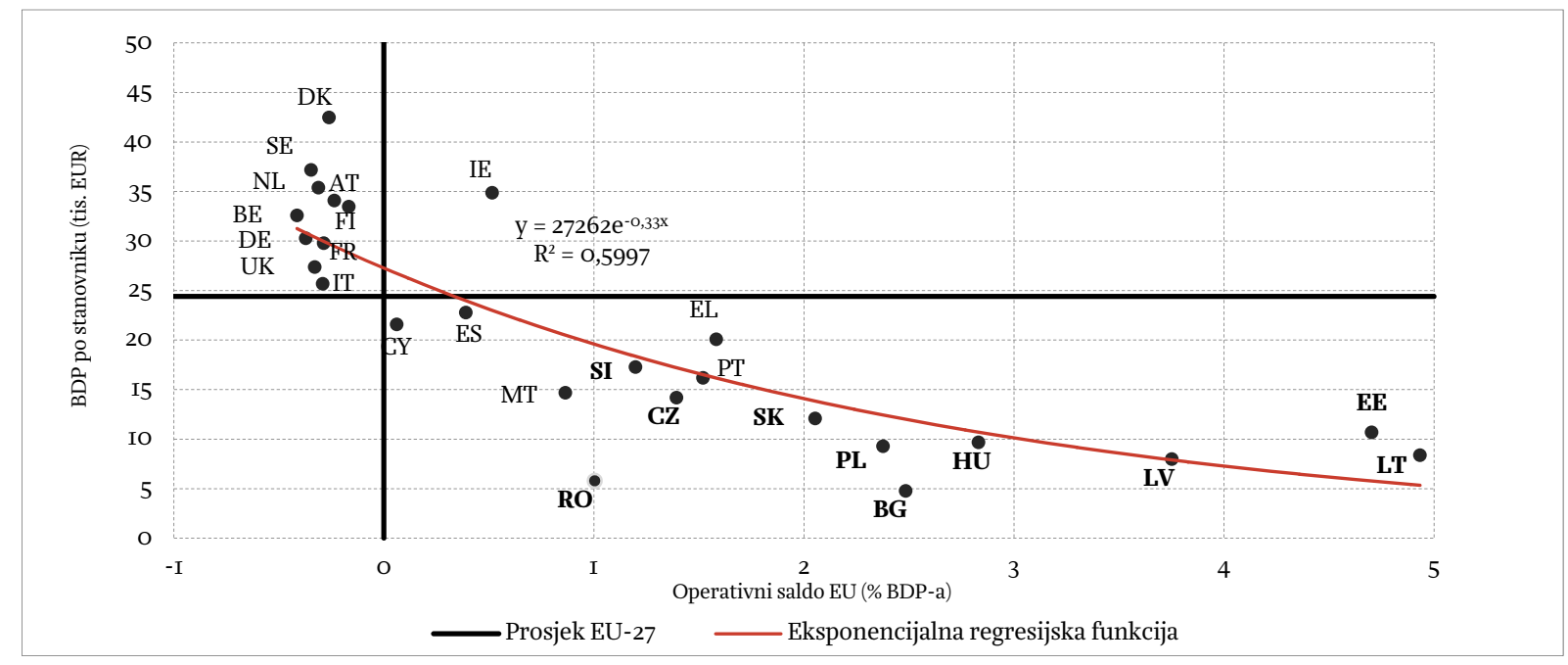

Izvor: izračun autora.

Operativni saldo prikazuje neto poziciju pojedine zemlje u EU proračunu, odnosno razliku uplata u EU proračun i isplata iz njega. Dijagram raspršenja operativnog salda EU proračuna i BDP-a po stanovniku svih zemalja članica pokazuje da postoji očigledna negativna veza između te dvije varijable, što znači da 
zemlje s višim BDP-om po stanovniku generalno ostvaruju niže neto financijske pozicije $s$ EU proračunom i obratno. Za modeliranje te veze pokazala se najboljom eksponencijalna funkcija koja iznimno dobro opisuje realizacije, što se pokazuje relativno visokim koeficijentom determinacije ( $R^{2}$ statistika) od 60\%. Detaljne statistike promatranog modela, odnosno njegove transformacije $\mathrm{u}$ linearni regresijski model, prikazane su u tablici $5^{\mathrm{I}}$. Zanimljivo je uočiti i da su sve nove zemlje članice neto primateljice sredstava iz EU proračuna pri čemu taj iznos varira od najmanjih I,2\% BDP-a kod Slovenije do najviših 4,9\% BDP-a kod Litve.

\section{TABLICA 5.}

Procijenjeni parametri i pokazatelji reprezentativnosti linearnog regresijskog modela kojim se modelira veza između logaritma BDP-a po stanovniku i operativnog salda EU proračuna

\begin{tabular}{|c|c|}
\hline Varijabla & Procjena $(t \text {-statistika })^{\mathbf{a}}$ \\
\hline \multirow{2}{*}{ Slobodni član $(\alpha)$} & 10,21323 \\
\hline & $(\mathrm{IOO}, 45)^{* * *}$ \\
\hline \multirow{2}{*}{ Koeficijent regresije $(\beta)$} & $-0,3302$ \\
\hline & $(-6, \mathrm{I} 2)^{* * *}$ \\
\hline Pokazatelj reprezentativnosti & Realizacija uzorka \\
\hline Suma kvadrata modela (SSR) & 7,16726 \\
\hline Suma kvadrata reziduala (SSE) & 4,78345 \\
\hline Ukupna suma kvadrata (TSS) & II,95O7I \\
\hline F-statistika & 37,46 \\
\hline p-vrijednost F-statistike & $<\mathrm{O}, \mathrm{OOOI}$ \\
\hline Koeficijent varijacije & 4,43442 \\
\hline Koeficijent determinacije $\left(R^{2}\right)$ & 0,5997 \\
\hline Prilagođeni koeficijent determinacije (Adj. $R^{2}$ ) & 0,5837 \\
\hline
\end{tabular}

Ukoliko pretpostavimo da modelirana veza između razine BDP-a po stanovniku i operativnog salda EU proračuna vrijedi općenito, može se procijeniti okvirna neto pozicija Hrvatske $u$ proračunu EU u pojedinoj godini uz pretpostavku da je BDP-a po stanovniku poznat. Projekcija BDP-a po stanovniku Hrvatske u tekućim cijenama u 2020. iznosi 15.445 EUR, a implicira neto primanje sredstava iz EU proračuna u ukupnom iznosu od I,72\% BDP-a, odnosno I,I3 mlrd EUR ${ }^{15}$. Ipak, valja naglasiti da je ova procjena napravljena temeljem postojećeg sustava financiranja EU proračuna, što znači da bi potencijalne promjene objašnjene u dijelu 3.I. mogle značajno izmijeniti konačan rezultat. Stoga ova procjena hrvatske neto pozicije prije ukazuju na potencijal Hrvatske u 2020., odnosno ne može se tumačiti kao direktna projekcija, budući da će konačna neto pozicija Hrvatske u proračunu EU ovisiti o

\footnotetext{
${ }^{\mathrm{I} 4}$ Napravljena je jednostavna transformacija eksponencijalnog modela $\mathrm{u}$ linearni regresijski model. Logaritmiranjem izraza $y=\alpha e^{\beta x}$ dobiva se linearna jednadžba $y^{\prime}=\alpha^{\prime}+\beta x$, gdje su $y^{\prime}=\log y$ i $\alpha^{\prime}=\log \alpha$. Iz navedenog slijedi da između logaritma BDP-a po stanovniku mjerenog standardom kupovne moći i operativnog salda EU proračuna postoji linearna veza.

${ }^{15}$ Procjena BDP-a za 2020. izračunata je iz aktualnih procjena rasta BDP-a i stopa inflacije za 20I2. i 20I3. dostupnih u priopćenju Ekonomskog instituta iz Zagreba (20I2) u kojem se predviđa realna stopa rasta BDP-a od -I,3\% u 20I2. i o,8\% u 2013. te stopa inflacije od 3,2\% u 20I2. i 2,6\% u 20I3. Nadalje, pretpostavlja se linearan rast realnog BDP-a do 2,5\% u 2OI7. (sukladno dugoročnim prognozama MMF-a, 2OI2) te stabiliziranje rasta na 2,5\% do 2020. U čitavom razdoblju 2014-202O. pretpostavlja se stabilna stopa inflacije od 2,5\%. Također, za BDP po stanovniku se implicitno pretpostavlja da neće biti prirodnog kretanja stanovništva, odnosno broj stanovnika u 2020. će biti jednak onome iz 2013.
} 
velikom broju varijabli koje je u ovom kontekstu nemoguće kvalitativno i kvantitativno opisati. Stoga sve dobivene rezultate valja tumačiti s posebnim oprezom.

\section{ZAKLJUČAK}

Ulaskom Hrvatske u EU dolazi do brojnih promjena koje će utjecati na neto novčane tokove iz EU proračuna prema hrvatskom proračunu i obratno. U 2013. Hrvatska će biti pola godine uključena u aktualnu financijsku perspektivu EU koja pokriva razdoblje od 2007-2013. Prema rezultatima procjene Hrvatska bi trebala ostvariti pozitivnu neto novčanu poziciju u iznosu od o,28\% BDP-a, odnosno I36 mil. EUR. Ukupna neto financijska pozicija Hrvatske zbog pristupanja EU u 20I3. uključuje još i dodatne troškove i koristi zbog pristupanja poput raznih usklađivanja te potrebe za sufinanciranjem projekata na državnoj i lokalnoj razini. Čak i u ovoj varijanti Hrvatske bi trebala biti u plusu i to u iznosu od oko o,15\% BDP-a, odnosno oko 72 mil. EUR.

Razdoblje od 2014-2O2O. pokriveno je novom financijskom perspektivom EU opisanom u višegodišnjem financijskom okviru. U prijedlogu ove financijske perspektive, aktualnom u trenutku pisanja rada, predlažu se brojne promjene u sustavu financiranja proračuna EU od kojih su svakako najvažnije ukidanje trenutnih prihoda na temelju PDV-a i uvođenje novih, uvođenje poreza na financijske transakcije, očekivano smanjivanje udjela prihoda na temelju BND-a te pojednostavljenje raznih korekcija. Međutim, valja naglasiti da se zasad radi samo o prijedlogu te je vrlo izvjesno da se u konačnici jedan dio predloženih promjena neće usvojiti. Usprkos tome, svakako je potrebno inicirati daljnje analize kojima bi se procijenile buduće implikacije ovih poreza na sve dionike u procesu, odnosno na konačne potrošače, financijski sektor te državne vlasti u Hrvatskoj.

Osim promjena $\mathrm{u}$ financiranju proračuna $\mathrm{EU}$, uvode se i neke promjene $\mathrm{u}$ financiranju iz proračuna EU. Nove predložene promjene financiranja iz sredstava europskih fondova trebale bi dovesti do ravnopravnije i poštenije raspodjele među zemljama članicama u svrhu provođenja kohezijske i Zajedničke poljoprivredne politike u skladu s dugoročnim ciljevima razvoja EU. Hrvatska bi u novoj financijskoj perspektivi od 20I4-2020. iz proračuna EU očekivano trebala povući sredstva vezana uz fondove u ukupnom iznosu od oko 5,2 mlrd. EUR, ali pritom je važno naglasiti da se taj iznos na godišnjoj razini kontinuirano povećava s O,4 mlrd. EUR u 2OI4. na I,I mlrd. EUR u 2O2O. Ukupan iznos svih sredstava koje bi Hrvatska mogla primiti u razdoblju od 2014-2020. iznosi 6,34 mlrd. EUR, pri čemu se iznos postepeno povećava iz godine u godinu počevši od o,7 mlrd. EUR u 2OI4. na I,2 mlrd. EUR u 2020. Eksponencijalnom regresijskom analizom iz povijesnih podataka novih zemalja članica procijenjeno je da bi očekivani hrvatski BDP po stanovniku u 2O2O. implicirao neto primanje sredstava iz EU proračuna u ukupnom iznosu od I,72\% BDP-a, odnosno I,I3 mlrd. EUR.

Važno je naglasiti da svi iznosi izloženi u radu predstavljaju tek očekivane procjene uz velik broj pretpostavki te je vrlo neizvjesno kakav će rezultat Hrvatska doista ostvariti od trenutka ulaska u EU sredinom 2013. pa sve do 2020. Svakako je potrebno razviti kvalitetnu strategiju unaprjeđenja apsorpcijskih kapaciteta za buduće razdoblje vodeći se iskustvima i najboljim praksama novih zemalja članica. Treba inicirati kontinuirano praćenje ostvarenja povučenih u odnosu na alocirana sredstva i 
projiciranje mogućih scenarija za buduće razdoblje. Takve bi analize trebale ukazati na sve potencijalne manjkavosti u postojećem procesu i dati jasne smjernice daljnjeg razvoja, odnosno poboljšanja. Nadalje, u ovom radu nisu bili obuhvaćeni širi potencijalni troškovi i koristi (ne nužno financijske prirode) od članstva u EU poput otvaranja europskog tržišta, razvoja konkurentnosti, političkih, socijalnih, regulatornih i ostalih promjena.

\section{REFERENCE}

I. Antczak, M., 2003. Do Acceding Countries Need Higher Fiscal Deficits? <e-book>. Available at 〈http://www.case.com.pl/upload/publikacja_plik/I5866ı_260.pdf .

2. Antczak, M., Dabrowski, M. and Gorzelak, M., 2004. Fiscal Challenges Facing the New Member States [online]. Paper for the DG EGFIN Workshop on 'Fiscal Surveillance in EMU: New Issues and Challenges', Brussels, November 12, 2004. Available at <http://ec.europa.eu/economy_finance/events/2004/bxliıo4/papers/dabrowski_en.pdf`.

3. Antczak, M., Markiewicz, M. and Siwinska, J., 2006. Fiscal pressures on the road to EMU [online]. Background paper to EFN report on 'convergence and integration of the new Member States to the Euro Area'. Available at <http://www.euroframe.org/fileadmin/user_upload/euroframe/efn/spring2006/EFN_Springo6_App_Antczak_et_al.pdf >.

4. Council directive II2/2006/EC of 28 November 2006 on the common system of value added tax.

5. Council directive 2008/II8/EC of I6 December 2008 concerning the general arrangements for excise duty and repealing Directive 92/I2/EEC.

6. Council directive 92/I2/EEC of 25 February 1992 on the general arrangements for products subject to excise duty and on the holding, movement and monitoring of such products.

7. Council of the European Union, 2005. Financial Perspective 2007-2013.

8. CPMR, 2OII. Financial Framework 20I4-2O2O: What is at Stake for Europe's Regions? Technical Paper from the CPMR General Secretariat [online]. Available at <http://www.crpm.org/pub/docs/329_tp_mff_en.pdf>.

9. Croatian Bureau of Statistics (CBS), 2012. Foreign trade in goods of the Republic of Croatia: January - December 20II. First Release, No. 4.2.I/I2. Available at 〈http://www.dzs.hr/Hrv_Eng/publication/2OII/O4-O2-OI_I2_2OII_corr.htm>.

Io. Cuculić, J., Faulend, M. and Šošić, V., 2004. „Fiscal Aspects of Accession: Can we Enter the European Union with a Budgetary Deficit?". Financial Theory and Practice, 28(2), pp. 155-179. Available at 〈http://www.ijf.hr/eng/EU2/cuculic-faulend-sosic.pdf〉.

II. Delegation of the European Union to the Republic of Croatia, 20I2. Overview of EU - Croatia relations [online]. Available at: 〈http://delhrv.ec.europa.eu/?lang=en\&content=62〉.

12. European Commission, 2007a. Screening report Croatia; Chapter 33 - Financial and budgetary provisions.

13. European Commission, 2007b. Pre-allocated funding for heading IB "Cohesion for growth and jobs" of the Financial Framework.

I4. European Commission, 2007c. Pre-allocated funding for "Rural development" under heading 2 "Natural resources" of the Financial Framework.

15. European Commission, 2009. Five years of an enlarged EU: Economic achievements and challenges.

16. European Commission, 20IIa. EU budget 2010 Financial Report.

17. European Commission, 20IIb. EU budget 20Io Financial Report - Detailed data 2000-20IO.

I8. European Commission, 20IIc. Croatia 20II Progress Report.

19. European Commission, 20IId. A Budget for Europe.

20. European Commission, 20IIe. A Budget for Europe - Part II: Policy fiches.

2I. European Commission, 20IIf. A Budget for Europe 2020: the current system of funding, the challenges ahead, the results of stakeholders consultation and different options on the main horizontal and sectoral issues.

22. European Commission, 20IIg. Financing the EU Budget: Report on the Operation of the Own Resources System.

23. European Commission, 20IIh. European Commission proposal for the 20I4-2020 Multiannual Financial Framework.

24. European Commission, 20IIi. Amended proposal for a COUNCIL DEGISION on the system of own resources of the European Union. 
25. European Commission, 20IIj. Amended proposal for a COUNCIL REGULATION laying down implementing measures for the system of own resources of the European Union.

26. European Commission, 2OIIk. Proposal for a COUNCIL DECISION on the system of own resources of the European Union.

27. European Commission, 2OIIl. Financing the EU Budget: Report on the Operation of the Own Resources System - Апnех.

28. European Commission, 2012. Statement of estimates of the European Commission for the financial year 2013 (Preparation of the 2013 Draft Budget).

29. Eurostat database [online]. Available at: 〈http://epp.eurostat.ec.europa.eu/portal/page/portal/statistics/search_database>.

30. Government of Republic of Croatia, 2010a. Izvješće o ispunjavanju obveza iz poglavlja i6. Porezi [online]. Available at: <http://www.mvep.hr/custompages/static/hrv/files/pregovori/5/pi6.pdf >.

31. Government of Republic of Croatia, 20Iob. Međuvladina konferencija o pristupanju Republike Hrvatske Europskoj uniji: Dodatak na Pregovaračko stajalište Republike Hrvatske za poglavlje I6. „Porezi“ (CONF-HR 8/O8) [online]. Available at: <http://www.mvep.hr/custompages/static/hrv/files/pregovori/4/I6a.pdf $>$.

32. Hallet, M., 2004. Fiscal Effects of Accession in the New Member States. European Commission. Economic Papers, No 203. [online]. Available at: 〈http://ec.europa.eu/economy_finance/publications/publication720_en.pdf>.

33. Halmai, P. i Vásáry, V., 20IO. Real Convergence in the New EU Member States of the European Union (Shorter and Longer Term Prospects) [online]. The European Journal of Comparative Economics, 7(I), pp. 229-253. Available at: 〈http://eaces.liuc.it/I824297920IOOI/I824297920IOO7OIIo.pdf >.

34. House of Lords, 2012. Towards a Financial Transaction Tax? [online]. European Union Committee, 29th Report of Session 20IO-I2. Available at: <http://www.publications.parliament.uk/pa/ld2OIOI2/ldselect/ldeucom/287/287.pdf $>$.

35. International Monetary Fund (IMF), 2006. Republic of Lithuania: 2006 Article IV Consultation Staff Report and Public Information Notice on the Executive Board Discussion [online]. IMF Country Report, No. 06/162. Washington, International Monetary Fund. Available at: 〈http://www.imf.org/external/pubs/ft/scr/2006/cro6i62.pdf .

36. International Monetary Fund (IMF), 20I2a. World Economic Outlook, April 2012 - Growth Resuming. Dangers Remain [online]. Washington: International Monetary Fund. Available at: 〈http://www.imf.org/external/pubs/ft/weo/2012/oI/pdf/text.pdf .

37. International Monetary Fund (IMF), 20I2b. World Economic Outlook Update, July 2012 [online]. Washington: International Monetary Fund. Available at: <http://www.imf.org/exte$\mathrm{rnal} / \mathrm{pubs} / \mathrm{ft} / \mathrm{weo} / 2 \mathrm{OI2} / \mathrm{update} / \mathrm{O} 2 / \mathrm{pdf} / \mathrm{o}$ I2.pdf $>$.

38. Kandžija, V. and Cvečić, I., 2OII. Ekonomika i politika Europske unije. Rijeka: Ekonomski fakultet.

39. Kulhánek, L., 20I2. Real convergence in Central and Eastern European EU member states. MPRA Paper, No. 39822 [online]. Available at: 〈http://mpra.ub.uni-muenchen.de/39822/I/MPRA_paper_39822.pdf >.

40. Kuliš, D., 20IO. What Is Expected from New Excise Duty Regulations in Croatia? [online]. Press Release, No. 23. Available at: 〈http://www.ijf.hr/eng/releases/23.pdf 〉.

4I. Ministry of Finance Time Series Data [online]. Available at: $<$ http://www.mfin.hr/en/time-seriesdata>.

42. Ministry of Finance, 20Io. Izvješće o korištenju pretpristupnih programa pomoći Europske Unije za razdoblje od I. srpnja do 3I. prosinca 20IO. [online]. Available at: 〈http://www.mfin.hr/adminmax/docs/Sabor\%2OII\%2Opolovica\%2O2OIO.pdf .

43. Ministry of Finance, 2012. Perspektiva sudjelovanja $\mathrm{RH}$ u europskim fondovima [ppt presentation]. Available at: <http://www.mfin.hr/adminmax/docs/mogucnosti\%2Ou\%2okoristenju\%2Ofondova.pps>.

44. Ministry of Foreign and European Affairs, 20II. Conference on Accession to the European Union Croatia (CONF-HR I7) [online]. Available at: 〈http://www.mvep.hr/custompages/static/hrv/files/pregovori/ZSEUEN/33.pdf $>$.

45. Money-Go-Round.eu database [online]. Available at: 〈http://www.money-go-round.eu/ >.

46. Osterloh, S., 20IO. The Fiscal Consequences of EU Cohesion Policy after 2013 [online]. Available at: $<\mathrm{http}: / /$ www.ief.es/documentos/recursos/publicaciones/revistas/presu_gasto_publico/57_o4.p df $>$. 
47. Sopek, P., 20II. Assessment of impact of accession to the EU on Croatian budget. Newsletter, No. 59 [online]. Available at: 〈http://www.ijf.hr/eng/newsletter/59.pdf >.

48. Sopek, P., 2012. Tax expenditures and the efficiency of Croatian value added tax. Financial Theory and Practice, 36(3), pp. 269-296 [online]. Available at: <http://www.ijf.hr/upload/files/file/FTP/2012/3/sopek.pdf>. doi: 10.3326/fintp.36.3.3

49. The European Bank Coordination ("Vienna") Initiative, 20II. The Role of Commercial Banks in the Absorption of EU Funds Report by the Working Group [online]. Available at: $<$ http://ec.europa.eu/economy_finance/articles/financial_operations/pdf/report_eu_funds_en. pdf $>$.

50. The Excise Duty Act, NN 83/o9. Zagreb: Narodne novine.

5I. The Institute of Economics, Zagreb, 2012. Priopćenje za javnost u povodu objavljivanja novog broja publikacije Croatian Economic Outlook Quarterly (br. 5I. srpanj 2012.) [online]. Available at: 〈http://www.eizg.hr/Download.ashx?FileID=528a7brb-e26f-42bo-9cıa-4097209arbir〉.

52. The Regulation on Excise Duty Rate on Cigarettes, NN IO2/IO. Zagreb: Narodne novine.

53. Vojinović, B. and Oplotnik, Ž. J., 2008. Real Convergence in the New EU Member States [online]. Prague Economic Papers, I. Available at: 〈http://www.vse.cz/polek/download.php?jnl=pep\&pdf $=317 . p d f>$. 